\title{
The Role of Freedom, Growth and Religion in the Taste for Revolution
}

\author{
Robert MacCulloch and Silvia Pezzini*
}

London School of Economics

DEDPS 36

The Suntory Centre

Suntory and Toyota International Centres for Economics and Related Disciplines

London School of Economics and Political Science Houghton Street

London WC2A 2AE

September 2002

Tel: (020) 79556674

Address for correspondence: Robert MacCulloch, STICERD, London School of Economics, Houghton Street, London WC2A 2AE. Phone: -44-207 955 6960, Email: robertmacculloch@,compuserve.com. Silvia Pezzini, STICERD, London School of Economics, Houghton Street, London WC2A 2AE. Phone: -44207852 3536. Email: s.pezzini@1se.ac.uk. 


\begin{abstract}
A fundamental issue for economists is what determines civil conflict. One unsettled question is the relative importance of political freedoms versus economic development. This paper takes a new approach to provide an answer by using micro-data based on surveys of revolutionary preferences of 130,000 people living in 61 nations between 1980 and 1997. Controlling for personal characteristics, country and year fixed effects, more freedom and economic growth both reduce revolutionary support. Losing one level of freedom, equivalent to a shift from the US to Turkey, increases support for revolt by 4 percentage points. To reduce support by the same amount requires adding 14 percentage points onto the GDP growth rate. Being Muslim in a free country has no effect on the probability of supporting revolt compared to a non-religious person. However being Muslim in a country that is not free increases it by 13 percentage points. Being Christian in a free country decreases the chance of supporting revolt by 4 percentage points, compared to a non-religious person, and in a not-free country by 1 percentage point.
\end{abstract}

JEL Classification: D74, H11, O1, O4.

Keywords: Conflict, Freedom, Development, Growth, Religion.

(C) The authors. All rights reserved. Short sections of text, not to exceed two paragraphs, may be quoted without explicit permission provided that full credit, including $(\odot)$ notice, is given to the source. 


\section{Introduction}

One of the suspected causes of civil conflict has been the denial of democratic freedoms to a nation's people. Whether or not to support regimes whose legitimacy is questioned for this reason has posed a foreign policy dilemma for the United States. In the case of Saudi Arabia, rather than push for political reform, one view argues that successive administrations have "indulged Riyadb's penchant for buying off trouble as long as the regime also paid its huge arms bills, purchased Boeing aircraft, kept the price of oil within reasonable bounds, and allowed the United States to use Saudi air bases". ${ }^{1}$ However the absence of freedom in Saudi Arabia has not been without its costs. These are difficult to directly quantify. Some trace the origins of the September $11^{\text {th }}$ World Trade Center attack to a perceived lack of legitimacy of the Saudi regime amongst groups of its people. Subsequent to this act of terrorism a new focus for US aid policy was announced, which stressed that "we must tie greater aid to political and legal and economic reforms. Our new approach for development ... must build the institutions of freedom". 2 There are several old and fundamental empirical questions that arise here. First, does lack of freedom result in greater support for rebellion? And if so, what is the cost of buying off the potential threat of greater instability? More formally, can we calculate a marginal rate of substitution between economic development and political freedoms, keeping the support for revolt unchanged? And is there evidence of a difference between Christians and Muslims? This paper is an attempt to answer these questions.

To do so, we take a different approach to previous studies by using a large international survey of the revolutionary tastes of over one hundred thousand people. We find that, controlling for the characteristics of people and countries, both the level of political and civil freedoms as well as the pace of economic development have marked and statistically robust effects on the taste for revolt. A loss of freedom has costs that appear to be large in economic terms. Dropping down one level of freedom (on a 1-3

\footnotetext{
${ }^{1}$ See Martin Indyk, Ex-US Ambassador to Israel, in Foreign Affairs (2002).
} 
scale) requires higher growth rates of 14 percentage points per year to keep the support for revolt unchanged. The effects are significantly stronger for Muslims. A policy of "buying off trouble" by going for growth when freedoms are denied appears to require close to unattainable rates of sustained economic growth.

This paper takes a different approach to previous empirical studies. Rather than focusing on the effect of freedoms and level of development on observable revolutionary actions at the aggregate level, our focus is on the micro-economic structure of revolutionary tastes. The source of this information is survey data that ask people whether they believe that "the entire way our society is organised must be radically changed by revolutionary action". This approach puts the present paper in the spirit of a growing literature in economics that has used survey data to test for the determinants of individual preference parameters. The World Values Data Set we use to measure revolutionary tastes was also used to obtain indicators of trust and civic norms in Knack and Keefer's (1997) study of the determinants of "social capital". Survey data were first significantly used in economics to help value public goods. Respondents were asked questions about their "willingness to pay" to, for example, save an endangered species. ${ }^{3}$ Luttmer (2001) used a U.S. General Social Survey question to help shed light on the determinants of the support for welfare spending. ${ }^{4}$ Respondents indicated whether they believed welfare spending to be "too high", "about right" or "too low". Luttmer identifies diminishing support for welfare spending as the share of local recipients from their own racial group falls. Alesina and La Ferrara (2000) studied preferences for redistribution, as proxied by a question asking whether "the government ought to reduce the income differences between rich and poor". Survey questions that ask respondents to judge the extent to which "improper practices (such as bribing and corruption) prevail in the public sphere" have been used to study the determinants of corruption in the economy. ${ }^{5}$ Another strand of literature in economics has studied the determinants of human well-being, as proxied by a survey

\footnotetext{
2 President George Bush, United Nations, Mexico, March 22, 2002.

${ }^{3}$ See Cummings, Brookshire and Schulze (1986) for a literature review.

${ }^{4}$ Boeri, Borsch-Supan and Tabellini (2001) studied support for welfare spending in Europe using survey data.
} 
question that asks a respondent "How happy are you?". A more closely related paper to the present one using survey data is Frey and Schneider (1978). It studies the determinants of the popularity of the U.S. President. However, rather than measuring approval ratings of one member or one party of government, our focus is on extreme dissatisfaction with the entire organization of a country.

Previous empirical studies have produced a diverse array of ambiguous findings on the relationship between freedom and the extent of civil conflict. ${ }^{7}$ A recent literature review lists "a number of possible causes of civil war [that] are still being debated". The first is "the role of political grievance and lack of democracy" (Sambanis (2001)). One strand of work, largely by economists, has argued that there is no significant relation between lack of democracy and the likelihood of there being an actual civil war. ${ }^{8}$ On the other side of the debate are several political scientists going back to Gurr (1970) who have argued that political grievance is the primary motive for civil violence. ${ }^{9}$ Even the role of economic development on conflict has proved controversial, with one review going so far as to state "that [empirical studies] show no consistent relation of level of economic development to political violence" (Coleman (1990)). ${ }^{10}$ The more recent assessment by Sambanis (2001) is more optimistic. He highlights several papers that argue that there is an empirically robust relationship between poverty, slow growth and an increased likelihood of civil war onset. ${ }^{11}$ However there is "disagreement [surrounding] the very definition of a civil war", the dependent variable used in all these quantitative studies. ${ }^{12}$ They have typically used an

\footnotetext{
${ }^{5}$ See, for example, Di Tella and Ades (1999) on how industrial policy affects malfeasance.

${ }^{6}$ Richard Easterlin (1974) began what remains a small literature. Clark and Oswald (1994) found that being unemployed had a large adverse impact on a person's self-reported well-being. Di Tella, MacCulloch and Oswald (2001) found negative effects on happiness of the inflation rate and the unemployment rate.

7 The literature on conflict largely begins with Karl Marx's (1887) Das Kapital. See also Haavelmo (1954), Tullock (1974) and Schumpeter (1991).

${ }^{8}$ Examples are Collier and Hoeffler (2000) and Fearon and Laitin (2001).

${ }^{9}$ Eldbadawi and Sambanis (2002), Esty et al (1998) and Reynal-Querol (2002) support this conclusion. Hegre et al (2001) find evidence of an inverted U-shaped relationship between the level of democracy and the risk of civil war onset. See also, inter alia, Tilly (1978), Tarrow (1989), Francisco (1993) and Gurr and Moore (1997).

${ }^{10}$ Huber, Rueschmeyer and Stephens (1993) study the relationship between level of development and democracy.

11 These include Collier and Hoeffler (2000) and Fearon and Laitin (2001). See also Alesina and Perotti (1996) who study the effect of inequality on political stability in order to estimate the effect of inequality on growth and Alesina, Özler, Roubini and Swagel (1996). MacCulloch (2000a,b) finds negative effects of GDP per capita and positive effects of income inequality on tastes for revolt using the Euro-Barometer Survey Series.

${ }^{12}$ See Sambanis (2001) for a discussion of the idiosyncratic definitions of civil war.
} 
absolute number of battle deaths as a threshold (say 1,000) that is not scaled by population size. Annual data on deaths can be difficult to obtain in many cases, making it "difficult to study conflict escalation and impossible to study conflict intensity". These problems imply that only limited time variation in the dependent variable has been able to be exploited. ${ }^{13}$ There are other reasons why actual conflict may have proven difficult to explain and predict. Revolutionary tastes arising from objective economic conditions may not translate into actions due to the free-rider problem that undermines collective action. ${ }^{14}$ This problem may be especially acute when an oppressive regime deliberately targets dissident groups. Such factors make it difficult to identify the causes of revolts whenever cross-country/regional data are used in studies whose dependent variable is the actual occurrence (or not) of violent uprisings. ${ }^{15}$

In Section II some simple theory is outlined to help motivate the empirical strategy. It is designed to emphasize the distinction between tastes for revolt and the (collective) action required to achieve one. Section III outlines the empirical strategy and introduces the World Values Survey that records the revolutionary tastes of approximately 130,000 people living in 61 countries between 1981 and 1997. These micro-data enable us to differentiate between the effects of both aggregate level variables such as freedom and GDP, as well as personal characteristics. Its panel dimension, taken over three time periods, means that we can control for unobserved heterogeneity using fixed effects. Section III reports several different validation exercises in which we correlate each respondent's taste for revolt with five different types of confrontational political action that the person may or may not have taken to achieve change (such as

\footnotetext{
13 There has also been a recent resurgence of interest in choice-theoretic models on conflict in economics. Part of the literature focuses on the choice between investing in productive or appropriative activities by different parties who are attempting to win control of a prize. Grossman (1991) explicitly models this choice in the context of a large group of people who are revolting against a regime. See also Acemoglu and Robinson (2000, 2001), Collier and Hoeffler (2000), Fearon and Laitin (2001), Garfinkel and Skaperdas (1996), Grossman (1994, 1999), Hirshleifer (1995), Skaperdas (1991, 1992), Roemer (1998), inter alia. Another strand of the literature focuses on the choice confronting an individual of whether to personally exert effort as part of a wider campaign of collective action. Recent examples include Kuran (1991) and Lohmann (1994) who show how protest activity can trigger a cascade of more protests that lead to the incumbent regime's collapse.

14 See Mancur Olson (1965), The Logic of Collective Action. As a result, a number of theorists have turned to the role of charisma of revolutionary leaders and ideology to help explain observed collective action.

15 The unpredictability and suddenness of actual revolts has been emphasized by Kuran (1991).
} 
occupation of buildings or factories). At the aggregate level, we correlate support for revolt with the occurrence or not of actual civil war in the corresponding country. Section IV describes the main results on what happens to tastes for revolt when either a country's level of freedom or its GDP changes. Section V reports results that exploit information contained in the Muslim and Christian sub-samples of the data set. Section VI provides some further checks on the results and Section VII concludes.

\section{Some Theory}

Let $y_{i}$ be an individual's income and $F$ represent an index of political and civic freedoms.

Let $U_{i}\left(c_{i}\right)$ be the utility function of individual $i$, where $U_{c}^{\prime}>0$ and $U_{c}^{\prime \prime}<0$ for all $i$. Let $E($.) be the expectation operator. Assume that individuals face a standard utility maximization problem but that in addition to their budget constraint they also face a constraint on their attainable levels of consumption due to state laws (for example, outlawing alcohol or restrictions on the type of clothing). The problem each individual solves is:

maximize $U_{i}\left(\underline{c_{i}}\right)$

such that $\underline{p . c_{i}} \leq Y_{i} \quad$ Budget Constraint

and $\quad \underline{c}_{i} \leq \underline{c}^{\max }(F) \quad$ Freedom Constraint

where $\underline{c}_{i}$ is a vector of consumption goods and $p$ is a vector of prices. The vector, $\underline{c}^{\max }(F)$, specifies the maximum consumption levels allowed for each good due to potential restriction of freedoms by the government. From problem (1) we can define each individual's indirect utility function, $U\left(Y_{\dot{\nu}} F, p\right)$.

Let an individual have a rational preference for revolt if he or she would experience an expected utility gain from one:

$$
\Delta_{i}=\mathrm{E}\left\{U_{i}\left(c_{i}^{\text {Revolt }}\right)\right\}-U_{i}\left(c_{i}^{\text {No Re volt }}\right)>0
$$


$\Rightarrow \Delta_{i}=\mathrm{E}\left\{U_{i}\left(Y_{i}^{\text {Revolt }}, F^{\text {Revolt }}, \underline{p}^{\text {Revolt }}\right)\right\}-U_{i}\left(Y_{i}^{0}, F^{0}, \underline{p}^{0}\right)>0$

where $Y^{\text {Revolt }}, F^{\text {Revolt }}$ and $p^{\text {Revolt }}$ are the levels of income, freedom and prices in the event of a revolt and $Y^{0}, F^{0}$ and $p^{0}$ are their initial levels in the absence of one. Equation (3) compares the expected utility derived from income and freedom obtained in the event of a revolt with the utility derived from existing income and freedom levels in the "no revolt" status quo. If $\Delta_{i}>0$ then the individual has a preference for revolt. A person's post-revolt income, $Y^{\text {Revolt }}$, may be expected to change depending on their pre-revolt income (i.e. whether the person is relatively rich or poor) as well as on the moments of the income distribution. Freedoms in the event of a revolt, $F^{\text {Revolt }}$, may or may not change depending on the policies of the new government.

\section{A Simple Case}

Let individuals have the separable indirect utility function, $U_{i}\left(y_{i}, F_{i}\right)=\alpha_{i} \log y_{i}+\beta_{i} \log F$ where $\alpha_{i}>0$ and $\beta_{i}>0$ are individual-specific parameters reflecting personal characteristics (such as religion or employment status). This functional form implicitly assumes that both the budget and freedom constraints in problem (1) are binding. Let $\bar{Y}^{0}$ be the initial mean level of income and $r_{i}^{0}=y_{i}^{0} / \bar{Y}^{0}$ be each individual's initial relative income position. In the event that a revolt occurs assume either that wealth is equally shared with no output loss (i.e. $y_{i}^{\text {Revolt }}=\bar{Y}^{\text {Revolt }}=\bar{Y}^{0}>1$ for $\forall i$ ), or that some output is lost leaving all incomes equal to unity. Let both outcomes occur with equal probability. Assume that everyone shares the same level of freedom in the absence of a revolt, $F^{0}$, and also in the event of one, $F^{\text {Revolt }}$. Hence a rational individual has a preference for revolt if his or her expected utility gain is positive:

$$
\Delta_{i}=\alpha_{i}\left(0.5 \log \bar{Y}^{0}+0.5 \log (1)-\log y_{i}{ }^{0}\right)+\beta_{i} \log \left(\frac{F^{\text {Revolt }}}{F^{o}}\right)>0
$$


$\Rightarrow \quad \Delta_{i}=-\alpha_{i} \log \left(r_{i}^{0} \sqrt{\bar{Y}^{0}}\right)+\beta_{i} \log \left(\frac{F^{\text {Revolt }}}{F^{0}}\right)>0$

Comparative static conditions derived from equation (4) are:

1. $\partial \Delta_{i} / \partial \mathrm{F}^{0}<0$

2. $\partial \Delta_{i} / \partial r_{i}^{0}<0$

3. $\partial \Delta_{i} / \partial \bar{Y}^{0}<0$.

These conditions state that for the present case revolutionary preferences depend negatively on the initial level of freedom, negatively on an each individual's relative income position and negatively on the average level of incomes. Since a higher initial level of freedom implies a higher level of utility relative to what one expects to receive in the event of revolt, the effect is to decrease the utility gain from revolt. $\Delta_{i}$ also decreases with relative income, $r_{i j}$ due to the assumption that everyone ends up with the same level of income in the event of a revolt occurring (so that the higher one's initial income is, the less one gains). The reason for the negative effect of mean income is that when people become absolutely better off, even relatively poor ones have more to lose if the revolt does not succeed. The size of each of these effects depends on the individual parameters, $\alpha_{i}$ and $\beta_{i}$.

We shall use data on revealed preferences for revolt as the (discrete) observation of the underlying continuous variable, $\Delta_{i}$. The objective of this paper is to test for the effects on one's taste for revolt of country freedoms, average income levels, each individual's relative income position and other personal characteristics. This will also allow us to "price freedom" in the sense of obtaining marginal rates of substitution between freedom and income, keeping revolutionary support constant.

\section{Preferences versus Actions}

Having a rational preference for revolt should be distinguished from actual participation 
in one. An individual may only be willing to exert effort to achieve radical social change, for example, to the extent that the free-rider problem is overcome. To illustrate, assume that it costs an individual $c\left(e_{i}, F\right)$ to exert effort $e_{i}$ on revolt (e.g. due to less work time and a corresponding lower wage income) where $c_{e}^{\prime}>0$ and $c_{F}^{\prime} \leq 0$. The latter condition may arise from a higher cost of acting against a more repressive government. Let average revolutionary efforts across the whole population be equal to $\bar{e}$ and the probability of a revolt actually occurring equal $p$, where $p$ is a function of $e_{i}$ and $\bar{e}$. Each individual chooses his or her level of effort to maximize expected utility, $E W_{i}=U_{i}\left(y_{i}^{0}, F^{0}\right)+p\left(e_{i}\right.$ $\bar{e}) \cdot \Delta_{i}-c\left(e_{i} F^{0}\right)$. Complementary slackness conditions are:

$p_{e_{i}}^{\prime}\left(e_{i}, \bar{e}\right) \cdot \Delta_{i}-c_{e_{i}}^{\prime}\left(e_{i}, F^{0}\right) \leq 0 \quad$ and $\quad e_{i} \geq 0$.

If the probability of a revolt occurring is independent of any individual's efforts then $p e_{i}^{\prime}\left(e_{i}, \bar{e}\right)=0$ and so $e_{i}=0$. In such a case, each person hopes to free-ride on the efforts of others but in equilibrium there is zero average effort and no actual revolt, despite the existence of people who may have a preference for this event (i.e. $\Delta_{i}>0$ ). Only when $p e_{i}^{\prime}\left(e_{\dot{v}}, \bar{e}\right)>0$ can there exist an interior solution.

Note that although a reduction in freedoms may increase the expected utility gain from a revolt for an individual (i.e. $\Delta_{i}$ increases) he or she may be less willing to exert effort to achieve one due to its higher cost (since $c_{e_{i}}\left(e_{i}, F^{0}\right)$ may also increase). Since we have micro-data on whether each individual has actually participated in collective action, such as mass protests and demonstrations, we are also able to study the connection between having a taste for revolution and the actions taken (or not) to achieve radical change. 


\section{Data Description and Validity}

\section{1. Data Description}

Revolutionary Preferences

The source of the data on the taste for revolt is the three waves of the World Values Survey Series (1981-84, 1990-92, 1995-97) that has interviewed a random sample of 168,482 individuals in 64 independent countries $^{16}$. Of these, 130,278 people in 61 nations have answered the following question: "On this card are three basic kinds of attitudes vis-à-vis the society in which we live in. Please choose the one which best describes your own opinion (one answer only)". The three relevant response categories are: "The entire way our society is organised must be radically changed by revolutionary action", "Our society must be gradually improved by reforms", and "Our present society must be valiantly defended against all subversive forces" (The "Don't know" and "Not asked in this survey" categories are not included in our data set). Appendix 1 provides a summary of the World Values Survey Series.

Table 1.1 shows the proportions of individuals who desire revolutionary action, versus those who do not (i.e. the ones who desire either gradual reforms or the present society valiantly defended) for the entire sample, the unemployed, male and female, religious persons and income quartile. Of the full sample, $9.8 \%$ of respondents declare a taste for revolution in their country. Of the unemployed, $14.1 \%$ prefer revolt. Of those people who belong to a religious denomination, $9.2 \%$ show a taste for revolution whereas for those who do not belong to a religion, 10.3\% want revolt. The breakdown between religions shows sizeable differences. Whereas $7.9 \%$ of Christians want revolt, $17.4 \%$ of Muslims do. There also exists a monotonically declining proportion of people who want revolt as we go up the income quintiles. In the first (or bottom) quintile, second quintile and third (or middle) quintile, there are 10.8\%, 10.4\% and 10.2\%, respectively, of respondents who want revolt. These numbers decline more sharply as we rise into the top group of income earners. For the $4^{\text {th }}$ quintile, $9.3 \%$ want revolt and for

\footnotetext{
${ }^{16}$ The countries surveyed include almost 80 percent of the world's population.
} 
the fifth (or top) quintile this proportion falls to $6.8 \%$.

\section{Freedom}

Our data on "Freedom" come from the Freedom House organization. This is an independent institutional effort to monitor the progress and decline of political rights and civil liberties in nations across the world. The annual survey is a year-long study produced by regional experts, consultants, and human rights specialist to gather in-depth knowledge of the political transformations affecting the countries studied, meeting a cross-section of political parties and associations, human rights monitors, religious figures, representatives of both the private sector and trade union movement, academics and journalists. Starting in 1972, Freedom House has published an annual assessment of state of freedom by assigning each country and territory the status of "Not Free", "Partly Free" of "Free". This one-to-three scale is obtained as follows.

First, political rights and civil liberties are rated separately on a seven-category scale, 1 representing the most free and 7 the least free. A country is assigned to a particular numerical category based on responses to the checklist and the judgments of the Survey team at Freedom House. To answer the political rights questions, Freedom House considers the extent to which the system offers the voter the chance to make a free choice among candidates, and to what extent the candidates are chosen independently of the state. To answer the civil liberties questions, the extent of freedom of expression, assembly, association, and religion are considered. These are distinguished by an established and generally equitable system of rule of law and are comparatively free of extreme government indifference and corruption. In particular, Freedom House follows a checklist of Political Rights and Civil Liberties, although it recognizes that formal procedures are not the only factors that determine the real distribution of power.

The Survey then assigns each country and territory the status of "Free," "Partly Free," or "Not Free" by averaging their political rights and civil liberties ratings. Those whose ratings average 1-2.5 are generally considered "Free," 2.5-5.5 "Partly Free," and 
5.5-7 "Not Free". Our variable, FREEDOM, is measured on a one-to-three discrete scale with the lowest value, 1, being assigned to "Not Free" countries and the highest value, 3, assigned to "Free" countries. We also use the two variables, POLITICAL RIGHTS and CIVIL LIBERTIES, which correspond to the Freedom House variables but are rescaled so that the lowest value, 1 , is assigned to countries with the least political rights/civil liberties and the highest value, 7 , is assigned to the countries with the most. For details of the checklists used for creating the scales, as well as for further information about their construction, see the Appendix.

\section{Religion}

The World Values Survey asks each respondent "Do you belong to a religious denomination? If yes, which one?". We first defined a dummy variable, Religious, equal to one if the respondent identifies herself as belonging to a religious denomination and zero otherwise. If the respondent does belong to a religion, we next code her into three broad religious groupings using the dummy variables, Christian, Muslim, and Other Religion. Of the full sample of 99,864 people who answered this question, 65.5 per cent declare themselves as belonging to one of the Christian faiths ("Roman Catholic", "Protestant" or "Russian/Greek Orthodox") and 7.0 per cent declare themselves as being "Muslim". The Other Religion category includes what was originally coded in the survey as being "Jewish", "Hindu", "Buddhist", or "Other". These four categories combined account for 9.9 percent of the full sample. The base category used for all these dummy variables is the group of people who say that they are "Not a member" or belong to "No religious denomination". For more details of the exact question that was asked, see the data definitions in the appendix.

\section{2. Data Validation}

It is possible to provide evidence that tastes for revolt are correlated with observable measures of conflict in society. Our dataset allows us to match the surveyed taste for 
revolt with forms of political action that the same person has undertaken at the time of, or prior to, the survey. These are: "signing a petition", "joining in boycotts", "attending lawful demonstrations", “joining unofficial strikes", and "occupying buildings or factories". The first may be taken more as an indicator of reformist action, whereas the other four as indicators of active involvement in changing society. We represent each political action by a dummy variable that takes the value 1 if the respondent has answered "Have done" and 0 if the answer was "Might Do" or "Would Never Do". Since all these variables are measured at the individual level, there are a total of 130,278 independent observations measured across all the countries and years in our sample.

Table 1.2 reports the Pearson correlation coefficients between a person's taste for revolt and the above indicators of actual protest. The taste for revolt is positively correlated with all of them, except for signing a petition. The correlation coefficients between taste for revolt and (a) joined in boycotts is 0.056, (b) lanfully demonstrated is 0.054 , (c) unofficial strikes is 0.059 and (d) occupied buildings is 0.06. These coefficients are all significant at the 1 per cent level. In contrast, signing a petition shows a small negative correlation (equal to -0.007 ) with declaring that society must be radically changed by revolutionary action, significant at the 5 percent level. This makes sense if signing a petition is regarded as being more of a reformist act than a revolutionary one. The indicators of actual protest are more highly correlated with each other than with the declared taste for revolt. For example, the correlation coefficient between "lawfully demonstrated" and "joined in boycotts" is 0.37 . There are two possible explanations for this result. First, stating the desire for a revolution may be judged more extreme than joining a boycott, demonstration, strike or occupation. Second, the collective action problem discussed in section II suggests that the mapping from preferences into actions is not one-to-one.

We regress each of these four indicators of actions (joined in boycotts, lawfully demonstrated, unofficial strikes and occupied buildings) on the individual's taste for revolt, controlling for country and year fixed effects. A declared taste for revolt is found to be a 
significant positive factor in determining the subversive actions of individuals at the 1 per cent level for all the measures of actual protest. ${ }^{17}$ An individual with a revolutionary taste has a 7 percentage point higher probability of joining in boycotts, 8 percentage point higher probability of demonstrating, 5 percentage point higher probability of joining unofficial strikes and a 3 percentage point higher probability of occupying buildings.

We also test for the relation between actual civil wars and revolutionary tastes using a data set of all civil wars in the world between 1944 and 1999 (see Doyle and Sambanis (2000)). A civil war is defined in this data set as a conflict between a government and a non-government claimant that has resulted in at least 1,000 deaths per year. There are 20 observations corresponding to countries and years in which actual civil wars occurred and for which we also have data on individuals' revolutionary tastes. The average support for revolt in these places is 14 percentage points (compared to 9 percentage points in the remaining sample). The Pearson correlation coefficient between the taste for a revolt and an actual civil war occurring in that country in the corresponding time period equals 0.07 , significant at the 1 percent level.

Consequently there appears a statistically significant link between an individual declaring that the established order should be changed by revolt and that same individual taking some form of revolutionary action. The size of the effect indicates that the majority are unwilling to take action, possibly for fear of reprisal or the presence of collective action problems. ${ }^{18}$

\section{Empirical Strategy}

We relate an individual's taste for revolt across a sample that includes 20 countries in 1981-84, 36 countries in 1990-92 and 45 countries in 1995-97 to his or her level of

\footnotetext{
17 These results are available on request.
} 
freedom (both civic and political), development as well as the relative income category (in quintiles) of each respondent. We also control for a larger set of both macroeconomic variables and individual characteristics. The results take advantage of both the cross-country and time series variation in the data.

The probit regressions are of the form:

TASTE for $=\alpha$ FREEDOM $_{c t}+\beta$ GDP per CAPITA $A_{c t}+\chi \Delta$ GDP per CAPITA $A_{c t}+$ REVOLT? $?_{i c t}+\delta$ PERSONAL INCOME GROUP ${ }_{i c t}+\gamma$ RELIGION $_{i c t}+\varphi M_{A C R O}+$ $+\lambda M I C R O_{i c t}+\eta_{c}+\mu_{t}+\varepsilon_{i t}$

where TASTE for REVOLT $T_{i c t}$ is a dummy variable that takes the value 1 when an individual, $i$, who lives in country $c$, and year $t$, agrees with the statement that "The entire way our society is organised must be radically changed by revolutionary action". The variable, FREEDOM $M_{c t}$ is an indicator of freedom measured on a 1-3 scale that assigns a country that is not free the value 1 , a partly free country with the value 2 , and a free country with the value 3. It comes from the annual survey by Freedom House.

The variable GDP per $C A P I T A_{c t}$ is used to proxy average income, $\bar{Y}$, in equation (2). It is measured as per capita income, in 1992 US\$, adjusted for purchasing power parity, in logarithms. $\triangle$ GDP per CAPIT $A_{c t}$ is the first difference of GDP per CAPITA $A_{c t}$ Since our measurements are in logs, $\triangle$ GDP per CAPIT $A_{c t}$ also equals $\log (1+$ annual GDP growth rate) which approximately equals the annual GDP growth rate (for growth rates $<10 \%$ ). These data come from the World Development Indicators of the World Bank. A person's relative income position in a country is proxied by the variable PERSONAL INCOME GROUP ${ }_{i t,}$, which assigns an income quintile to each respondent to the revolt question. RELIGION ${ }_{i c t}$ enters both as a dummy indicating whether each person is religious, and also as a vector of the different religions to which he or she may belong. The main categories that we divide the sample into are Christian, Muslim, and Other.

\footnotetext{
18 There also exists a significant positive relationship between reported criminal actions (as measured by both serious assault and auto-theft) and surveyed preferences for revolt taken across 201,940 randomly sampled people in Europe, controlling
} 
The vector $M A C R O_{c t}$ refers to a set of variables aggregated at the country level that may also affect the support for revolt. These include the Inflation Rate and Openness. The former is measured by the annual rate of change in consumer prices (in logs). ${ }^{19}$ The latter is measured by the sum of imports and exports divided by the country's total GDP. A proxy for the level of education in each country is also used, Primary Education, which is the ratio of total enrolment in primary level education, regardless of age, to the population of the age group that officially corresponds to this level of education. For further details about how each of these variables was constructed, see the data definitions in the appendix. The vector $M I C R O_{i c t}$ refers to a set of personal characteristics of the respondents including their employment status, marital status, age and level of education. The appendix contains a complete set of data definitions. We also include $\eta_{c}$, which is to a dummy variable for each cross-sectional unit (i.e. countries) and $\mu_{t}$, which is a dummy variable for each year. The (i.i.d.) error term is $\varepsilon_{i c t}$. Robust standard errors are computed to correct for potential heteroskedasticity and for potential correlation of the error term across observations that are contained within a cross sectional unit in any given year (see Moulton (1986)). Table 1.3 provides summary statistics of the variables used.

\section{Omitted Variable Bias and Exogeneity}

There are other variables that may have still have been omitted from our regressions and are affecting the taste for revolt. The inclusion of both country and year fixed effects in all our regressions goes some way to controlling for unobserved heterogeneity that could be biasing the results. As a further check, we attempt to control for income inequality, although data availability seriously constrains this task.

Another issue is the possibility of endogeneity due, for example, to increased

\footnotetext{
for country and year fixed effects (see MacCulloch (2000a,b)).

${ }^{19}$ Taking logs helps control for the effects of outliers in the sample, such as the hyperinflation during the 1980s in Argentina in which inflation was 630 percent per annum.

${ }^{20}$ Most studies of civil war have ignored issues of endogeneity (see Sambanis (2001)).
} 
support for revolt resulting in changes to policies and the economy. This issue has received little attention in the previous literature. ${ }^{20}$ It remains unclear what sign any effect of higher support for revolt could have on freedom since greater revolutionary pressures may lead to either greater freedom or greater repression. ${ }^{21}$ It remains a controversy in the literature the extent to which deep preference parameters actually do affect policy outcomes. ${ }^{22}$ Alternatively, revolutionary tastes might be thought of as being a determinant of economic growth. To make this link possible, the transmission mechanism must run from preferences for revolt into actions and from there to changes in GDP. While the first part of the chain appears to exist in our data (the correlation coefficients between actions and preferences are, on average, equal to 0.057 and significant at the 1 percent level) the size of the mapping is much less than one to one. This could be due to collective action problems, as already outlined. Endogeneity would be stronger if we were using actual outcomes of civil war as a left-hand side variable, so our approach appears an improvement on this front. Moreover, we make a simple attempt to address these issues by re-estimating the above set of regressions, but including lagged values of Freedom rather than current ones.

\section{The Relationship between Revolutionary Tastes and Freedom}

\section{1. The Price of Freedom: Basic Results}

In Table 2.1, columns (1) to (6) present the first set of results, estimated using probit regressions. Marginal probabilities are reported and all regressions control for both country and year fixed effects. Column (1) shows the relation between the level of freedom in nations and the corresponding taste for revolution. The coefficient on Freedom is negative and significant, at the 1 per cent level. An individual living in a

\footnotetext{
${ }^{21}$ As an example of the former, in early seventeenth century England, fiscal needs of the Crown led to "expropriation of wealth through redefinition of rights in the sovereign's favor" and subsequently civil war. After the Glorious Revolution of 1688, the winners (the Whigs) sought to redesign government institutions in such a way as to control the problem of "the exercise of arbitrary and confiscatory power by the Crown" (North and Weingast (1989)).

22 See, for example, Persson and Tabellini (2000).
} 
country that loses one degree of freedom on a 1 to 3 scale (which is equivalent to a shift from a "Free" country like the United States to a "Partly Free" country like Turkey) experiences an increase in their probability of supporting a revolt by 3.2 percentage points. $^{23}$

Column (2) runs a similar regression but now includes the level of GDP per capita (measured in logs) as a predictor of revolutionary tastes, in addition to the level of Freedom. The coefficient on GDP per capita is weakly significant at the 10 percent level. Column (3) includes the change, as well as the level of GDP per capita. The coefficient on the level term remains negative but loses significance, whereas the change term is negative and significant at the 5 percent level. Its size indicates a person living in a country that experiences a real growth rate of 10 percentage points per year is expected to have a 2.0 percentage points lower probability of desiring revolution than if the growth rate was zero $(=0.201 * \Delta \log (G D P$ per capita $)=0.201 * \log (1+$ growth rate $) \approx$ $0.201 *$ growth rate $=0.201 * 0.10=0.02)$. The coefficient of Freedom, equal to -0.035 , remains similar in size to the previous two specifications remains and also retains its 1 per cent level of significance. Column (3) seems to lend support to the view that economic growth matters more than the absolute level of income in depressing people's desire for revolutionary change.

In addition to Freedom and GDP per capita levels and changes, column (4) includes each individual's relative position in the income ladder as a possible factor explaining his taste for revolt. The relative income position is measured in terms of quintiles. The results show a monotonically decreasing effect on having a revolutionary taste as one goes up the income groups. Relative to a person in the bottom group, rising up one income quintile implies a 0.4 percentage point lower probability of desiring revolt, rising up two quintiles implies a 0.9 percentage point lower probability of desiring revolt (significant at the 5 percent level), rising up three quintiles implies a 0.9 percentage point

\footnotetext{
${ }^{23}$ A drop of one level of the Freedom index is also equivalent to a shift from "Partly Free" Turkey to a "Not Free" country like North Korea or Saudi Arabia.
} 
lower probability of desiring revolt (significant at the 5 percent level) and rising up four quintiles implies a 1.2 percentage point lower probability of desiring revolt (significant at the 5 percent level). Going from the bottom to the top income quintile implies a 2.0 percentage point lower probability of desiring revolt (significant at the 1 percent level). This regression suggests each individual's own position in the income distribution of a country, as well as the existence of aggregate economic growth, contribute to buying off revolutionary tastes. The coefficients on Freedom and $\triangle G D P$ per capita also remain negative and significant at the 1 percent level in column (4), equal to -0.036 and -0.277 , respectively.

Altogether, the previous regressions give a picture of freedom, economic growth and an individual's relative income as shaping the taste for revolt in nations. Since both Freedom and the change in GDP per capita enter negatively and significantly we are able to calculate a marginal rate of substitution between these two variables (keeping the taste for revolt constant). Using the coefficients on these variables from column (4), a loss of one degree of freedom (on the 1 to 3 scale) increases the probability of preferring revolt by 3.6 percentage points and so would have to be compensated by an increase in the GDP per capita growth rate of 13.9 percentage points $\left(=\log ^{-1}(0.036 / 0.277)\right.$ - 1). For example, the growth rate would have to rise from 1 to $14.9 \%$ per annum in order to keep an individual's taste for revolt unchanged in the face of a drop of one degree in the level of freedom (i.e. going from the US down to Turkey or from Turkey down to Saudi Arabia). Even a rise from the bottom to the top of the income distribution, which lowers the chance of preferring a revolution by 2.0 percentage points, is insufficient to compensate the individual for a one-degree drop down the freedom scale.

Finally, columns (5) and (6) in Table 2.1 repeat the basic specification in column (4) but use the two separate indices, Civil Liberties and the Political Rights (both based on a 1 to 7 scale), from which the Freedom scale is derived as an average of the two. They both have negative and significant effects at the 1 percent level on revolutionary tastes. Similarly the coefficients on the Personal Income Quintiles and $\triangle G D P$ per capita are also 
similar in size and significance to the previous columns, with the exception of the change in GDP per capita which loses significance in column (6).

\section{2. Muslims, Christians, Income and the Taste for Revolt}

Table 2.2 investigates the role of religion, and in particular of being a Christian or a Muslim, on one's taste for revolt. We first investigate whether there are different effects, on average, of being a member of one of these religions. We next interact freedom with religious affiliation to determine if members of these religions respond differently to a denial of their freedoms.

Column (1) includes the dummy variable, Religious, which takes on the value 1 when the respondents identify themselves as belonging to a religion. It also includes the basic set of variables measuring Freedom and income, both at the aggregate and individual level, which were used in column (4) of Table 1.1. A full set of country and year fixed effects are also present. Being religious has a negative effect on having a revolutionary taste, at the 1 percent level of significance. It lowers the probability that an individual prefers revolt by 3.0 percentage points. The coefficients on the aggregate variables, Freedom and $\triangle G D P$ per capita, remain similar in size and significance levels to their corresponding values in column (4) although the level of GDP per capita now becomes significant at the 10 percent level. Its magnitude, however, is only 11 percent of the magnitude of $\triangle G D P$ per capita. Column (2) divides individuals into three separate religious categories, Christian, Muslim and Other Religions. The base category is belonging to no religious denomination. Christians have significantly less chance of preferring revolt compared to people who are not religious, whereas for Muslims and other religions there is no difference. The coefficients on Christian, equal to -0.034, and Muslim, equal to -0.007 , are significantly different at the 1 percent level.

Column (3) tests for whether the taste for revolt amongst religious individuals differs according to the degree of freedom in their country. The evidence suggests that it does since the interaction term, Religious*Freedom, is negative and significant at the 10 
percent level. In other words, whereas being religious in a "Free" country decreases an individual's chance of preferring revolt by 4.5 percentage points $\left(=0.015^{*} 3\right)$, in a "Not Free" country it only decreases by 1.5 percentage points $\left(=0.015^{*} 1\right)$, when compared to a non-religious person. Column (4) divides religious individuals into three separate groups to study interaction effects. Whereas the coefficient on Muslim, which equals 0.188 , is positive and significant at the 5 percent level, the interaction term of Muslim*Freedom, which equals -0.062 , is negative and significant at the 1 percent level. These two coefficients imply that being Muslim in a "Free" country has almost no effect on the probability of preferring a revolt compared to a non-religious person $(=0.188$ $3 * 0.062=0.002)$. However being Muslim in a "Not Free" country increases the probability of having a revolutionary taste by 12.6 percentage points compared to a nonreligious person $(=0.188-1 * 0.062)$. There are strong differences between Christians and Muslims. Being Christian in a "Free" country decreases the probability of preferring revolt by 4.1 percentage points compared to a non-religious person $(=0.004-3 * 0.015)$, but in a "Not Free" country it decreases it by only 1.1 percentage points $(=0.004-$ $1 * 0.015){ }^{24}$

There does exist the possibility of differential effects on revolutionary tastes between being a Muslim in a country where Muslims are a majority and where they are a minority. ${ }^{25}$ To shed some light on this issue, Tables $1.4 \mathrm{a}$ and $\mathrm{b}$ list the countries in which more than 1 percent of the population is Muslim, along with the corresponding support for revolution across the whole sample and within the Muslim sub-sample. The overall average level of support for revolt amongst Muslims who live in countries where they are a minority is 10.6 percent. Within these countries, the average support for revolt by Muslims ranges from 1.7 percent in "Free" countries to 11.6 percent in "Partly Free"

\footnotetext{
${ }^{24}$ The results suggest that whether or not religion is "the opium of people" as argued by Marx (1844) depends both on the identity of the religion and the degree of freedoms enjoyed by religious individuals. For example, although Christians do have, on average, a 3.4 percentage point lower probability of preferring revolution than non-religious people, this falls to a 1.1 percentage point difference in a "Not Free" country. In the case of Muslims, there is no difference between their revolutionary preferences and non-religious people, but in a "Not Free" country they have a 12.6 percentage point higher probability of preferring revolution.
} 
countries to 22.1 percent in "Not Free" countries. Within the countries where Muslims are a majority, no countries in the World Values Survey are classified as "Free" and the average support for revolt by Muslims ranges from 18.7 percent in "Partly Free" countries to 24.9 percent in "Not Free" countries. The overall average level of support for revolt by Muslims in countries where they are the majority equals 20.3 percent. Moreover, in a regression that includes an interaction term of freedom with the respondent being part of a minority there is some effect that people from a Christian or Muslim minority react more strongly to the denial of freedom than if they were part of the majority. In addition, Muslims always have a higher level of taste for revolt than Christians, for any combination of freedom status and minority/majority grouping. ${ }^{26}$

We also test for the mechanism underlying the different reaction to freedom by Christians and Muslims by checking whether the two religious groups react differently to the denial of political rights or civil liberties ${ }^{27}$. The idea is that Muslims might care more when their political rights are taken away than when their civil liberties are, because the prescriptions on civil liberties that they have to follow descend directly from their religion and thus are more easily justified. The results lend support to this hypothesis. When political rights are used as the explanatory variable, Muslims react twice as strongly to the denial of rights than Christians. Using civil liberties, however, does not yield any significant result. This leads to the policy conclusion that if a government wants to decrease the support for revolt in countries in crisis, political rights should be granted, while the extent of civil liberties should not be in question.

Columns (5) and (6) investigate the possibility that the change in GDP per capita might affect an individual's taste for revolt differentially depending on whether they are religious or not. The reason is to test the idea that religious people may be more difficult to "buy off' than non-religious ones, due to their ideology. Column (5) includes the

\footnotetext{
25 There could also be a difference between Muslims depending on whether their state is governed by an Islamic religious group or not, but the only country which can be strictly defined as a theocratic regime is Iran.

26 All results not reported in tables are available on request.

27 We remind the reader that the freedom score is the average of the civil liberties and political rights indices.
} 
interaction term, Religious* $\triangle G D P$ per capita, which is insignificant. The last column divides up religious people into Christians, Muslims and Other Religions. The coefficients on the interaction terms of these first two groups with $\triangle G D P$ per capita are also both insignificant. There is a weak effect (at the 10 percent level) of economic growth leading to a stronger reduction in the taste for revolt amongst the Other Religious groups. ${ }^{28}$

\section{Further Checks and Tests on the Results}

\section{1. Weighted Least Squares}

The World Values Survey uses a stratified multi-stage random sampling method and has approximately 1,500 respondents for each survey in each country. Thus, every country's survey gives a representative picture of that whole country. Nevertheless, by giving each of the respondents an equal weight, we tend to underestimate the weight of large countries and overestimate that of small countries. In order to give a picture of the whole world population that reflects the true mix of its characteristics we repeat the whole set of regressions using weighted least squares, where the sampling weights used denote the inverse of the probability that an individual is included in his or her country sample due to the above sampling design. ${ }^{29}$

The results are consistent with the above findings. All the effects remain consistently valid, while some become reinforced. The effect of average income in decreasing support for revolt becomes stronger and significant at the 1 percent level throughout all the specifications. The difference between Muslims and Christians in their reaction to the denial of freedom remains significant, although the size of the difference becomes smaller. The coefficients imply that being Muslim in a "Free" country decreases the probability of having a revolutionary taste by 5.3 percentage points compared to a

\footnotetext{
${ }^{28}$ We also tested for interaction effects between the level of GDP per capita and the different religious groups. These are not significant (available on request).

${ }^{29}$ In particular this procedure ensures that the results reflect the true proportions of the different religious groups in the world (where Muslims represent 22\% and Christians 33\% of people).
} 
non-religious person (the effect equals zero in the non-weighted regressions). However being Muslim in a "Not Free" country increases the probability of having a revolutionary taste by 4.1 percentage points compared to a non-religious person (the effect equals 12.6 percent in the non-weighted case). Being Christian in a "Free" country decreases the probability of preferring revolt by 9.3 percentage points compared to a non-religious person, but in a "Not Free" country it decreases it by only 3.1 percentage points. Using weighted least squares there also now exists a differential effect depending on whether the respondent is in a minority religious group. For example, being in a Christian or Muslim minority increases the support for revolt by 5 percentage points (there was no significant effect in the non-weighted case).

\section{2. Adding More Controls and Endogeneity}

Table 2.3 performs a set of robustness checks on the above specifications of the determinants of the taste for revolt. We focus on the basic specification that includes the variables, Freedom, the level and change in GDP per capita, Personal Income Quintile and Religious. Column (1) includes three macroeconomic controls: the inflation rate, openness to trade and the level of primary education in the country. The effects of freedom, GDP per capita, personal income and religion on revolutionary tastes all remain similar in size and significance to their values reported in the previous tables. More inflation and openness both have negative effects on the support for revolt at the 5 percent level, while the level of primary education in the country has no significant impact. ${ }^{30}$ For example, an increase in the inflation rate from 1 to 11 percentage points decreases the chance of desiring revolt by 2.9 percentage points and an increase in openness of 10 percentage points decreases the chance of desiring revolt by 1.4 percentage points. To further investigate the negative effects of the Inflation Rate and Openness, we interact each of these variables with the personal income quintiles. The interaction terms with Openness are all insignificant. Inflation, on the other hand, has a different impact across the 
different quintiles. It has less effect on reducing the taste for revolt for individuals in the top quintile relative to the bottom quintile.

Columns (3) and (4) expand the set of possible controls to also include a set of individual characteristics. In column (3), employment status has strong effects on one's taste for revolt. Compared to working, being unemployed or a student increase the probability of supporting revolt by 2.0 and 1.7 percentage points, respectively. ${ }^{31}$ Being retired or a housewife decreases the probability of supporting revolt by 2.5 and 1.9 percentage points, respectively. These four coefficients are all significant at the 1 percent level. The effects of our basic set of aggregate variables (Freedom plus the level and change in GDP per capita) remain almost unchanged. Column (4) also includes controls for an individual's marital status, age, gender, schooling and number of children. Being married or widowed (compared to being single) or older than 25 years reduces one's taste for revolt. On the other hand, being male or having one child only, increases support for revolt. These last two regressions test for robustness of our basic model using over 70 additional control variables simultaneously (including country and year effects).

In addition to controlling for unobserved heterogeneity by the inclusion of both country and year dummies, as a further check on the results we also tried controlling for the effects of income inequality using the Deininger and Squire (1996) data set. Due to limited availability of the "high quality" series of Gini coefficients for the countries and years in our sample, we could only exploit 18.9 percent of the size of the original sample. This small data set provides us with too few country/year observations to reliably identify effects on inequality, freedom and GDP per capita on revolutionary tastes including fixed effects. Consequently we proceed by linearly interpolating the inequality data, although for a number of countries income inequality data are unavailable for any year. In a regression explaining the taste for revolt, the coefficient on the level of Income

\footnotetext{
30 If greater openness reduces rents by making the domestic economy more competitive, this could explain its negative effect to the degree that conflict is caused by rent-seeking behavior (see, for example, Collier and Hoeffler (2000)).

31 Aggregate unemployment rate data are unavailable for the majority of the countries and years in our sample.
} 
Inequality (as measured by the Gini) is positive and significant at the 10 percent level (using 80,790 observations of individuals). In other words, there is some evidence that greater inequality exacerbates revolutionary tastes. The coefficient on Freedom in this regression equals -0.047 , significant at the 1 percent level, and on $\triangle G D P$ per capita equals -0.650 , significant at the 1 percent level. There is also a monotonically declining effect on the probability of preferring revolt as one goes up the income quintiles. In addition, we have explored the possibility that economic growth may affect tastes for revolt differently if accompanied by greater or smaller inequality, but we have not obtained any robust result.

In a simple attempt to address the endogeneity issue, we repeat the whole analysis using a lagged value of Freedom. The results are consistent with the ones obtained previously. In particular, in the same regression specification as in column (4) of Table 2.3, the coefficient on Freedom (t-1) is equal to -0.016 , which is still significant the 1 percent level (compared with -0.027 in the corresponding specification using the current level of Freedom).

\section{Conclusion}

This paper takes a new approach to help answer an old and unsettled question on civil conflict: what is the relative importance of political freedoms compared to economic development? It also studies whether there are differences between the two main religious groups in the sample, Christians and Muslims. To do so, we introduce a microdata set based on surveys of the revolutionary tastes of 130,000 people living in 61 nations between 1981 and 1997. The approach differs from previous studies that have typically used aggregate level data on actual civil wars.

We provide several different types of evidence that tastes for revolt are correlated with observable measures of conflict in society. These include matching the surveyed tastes with forms of political action that the same person has undertaken. These include 
joining in boycotts, attending demonstrations, joining unofficial strikes and occupying buildings or factories. The correlation coefficients between these actions and a person's taste for revolt are strongly significant at the 1 per cent level and lie between 0.05 and 0.06. Using a separate data set on civil wars in countries, we find that the correlation coefficient between the taste for revolt and an actual civil war occurring in that country over the corresponding time period is equal to 0.07 , significant at the 1 percent level.

We next study the determinants of revolutionary tastes. Controlling for the personal characteristics of the respondents, country fixed effects, year fixed effects and using both weighted and unweighted least squares, less people support revolt when they live in a country that is relatively free or has a high level of GDP per capita growth. An individual living in a country that loses one degree of freedom on a 1 to 3 scale (equivalent to a drop from the US to Turkey or from Turkey down to Saudi Arabia) experiences an increase in their probability of preferring a revolution of 3.6 percentage points. This would have to be compensated by an increase in the GDP per capita growth rate of 13.9 percentage points in order to keep the individual's taste for revolt unchanged. There also exists a monotonically decreasing effect on revolutionary tastes as one goes up the income groups. Going from the bottom to the top income quintile implies a 2.0 percentage point lower probability of desiring revolt.

There are strong effects of religious affiliation on revolutionary tastes. Religion lowers the probability that an individual prefers revolt by, on average, 3.0 percentage points. Strong differences exist between Christians and Muslims. Being Muslim in a "Free" country has almost no effect on the probability of preferring a revolt compared to a non-religious person. However being Muslim in a "Not Free" country increases the probability of having a revolutionary taste by 12.6 percentage points compared to a nonreligious person. Being Christian in a "Free" country decreases the probability of preferring revolt by 4.1 percentage points, compared to a non-religious person, and in a "Not Free" country decreases it by 1.1 percentage points. These results occur most strongly on the political rights (rather than the civil liberties) component of freedom. 
Table 1.1

Tastes for Revolution: 61 nations, 1981 to 1997.

\begin{tabular}{|c|c|c|c|c|c|c|c|}
\hline \multirow{2}{*}{$\begin{array}{l}\text { TASTE for } \\
\text { REVOLT? }\end{array}$} & \multirow[b]{2}{*}{ All } & \multirow[b]{2}{*}{$\begin{array}{c}\text { Unemploy } \\
\text { ed }\end{array}$} & \multicolumn{2}{|c|}{ Religious? } & \multicolumn{3}{|c|}{ If religious: } \\
\hline & & & Yes & No & $\begin{array}{c}\text { Christia } \\
\mathrm{n}\end{array}$ & $\begin{array}{c}\text { Musli } \\
\text { m }\end{array}$ & $\begin{array}{c}\text { Othe } \\
r\end{array}$ \\
\hline Yes & 9.8 & 14.1 & 9.2 & 10.3 & 7.8 & 18.3 & 12.9 \\
\hline No & 90.2 & 85.9 & 90.8 & 89.7 & 92.2 & 81.7 & 87.1 \\
\hline \multirow{2}{*}{$\begin{array}{l}\text { TASTE for } \\
\text { REVOLT? }\end{array}$} & \multicolumn{7}{|c|}{ Income Quintiles } \\
\hline & & $\begin{array}{c}1^{\text {st }} \\
\text { (Lowest) }\end{array}$ & $2^{\text {nd }}$ & $3^{\text {rd }}$ & $4^{\text {th }}$ & \multicolumn{2}{|c|}{$\begin{array}{c}5^{\text {th }} \\
\text { (Highest) }\end{array}$} \\
\hline Yes & & 10.8 & 10.4 & 10.2 & 9.3 & \multicolumn{2}{|c|}{6.9} \\
\hline No & & 89.2 & 89.6 & 89.8 & 90.7 & \multicolumn{2}{|c|}{93.1} \\
\hline
\end{tabular}

Note: All figures are based on the full sample of 130,278 people and are expressed as percentages. In the religion category, "Other" includes what was originally coded in the World Values Survey as "Jew", "Hindu", "Buddhist" or "Other". 


\section{Table 1.2}

Correlation Coefficients between Tastes for Revolt and Revolutionary Actions: 61 nations, 1981 to 1997.

\begin{tabular}{|c|c|c|c|c|c|c|}
\hline & $\begin{array}{c}\text { Taste } \\
\text { for } \\
\text { Revolt? }\end{array}$ & $\begin{array}{l}\text { Signed a } \\
\text { Petition }\end{array}$ & $\begin{array}{l}\text { Joined in } \\
\text { boycotts }\end{array}$ & $\begin{array}{c}\text { Lawfully } \\
\text { demonstrated }\end{array}$ & $\begin{array}{l}\text { Unofficial } \\
\text { strikes }\end{array}$ & $\begin{array}{c}\text { Occupied } \\
\text { buildings/ } \\
\text { factories }\end{array}$ \\
\hline Taste for Revolt? & 1 & & & & & \\
\hline Signed a petition & -0.007 & 1 & & & & \\
\hline Joined in boycotts & 0.056 & 0.294 & 1 & & & \\
\hline Lawfully demonstrated & 0.054 & 0.311 & 0.368 & 1 & & \\
\hline Unofficial strikes & 0.059 & 0.165 & 0.291 & 0.328 & 1 & \\
\hline Occupied & 0.060 & 0.112 & 0.211 & 0.210 & 0.307 & 1 \\
\hline buildings/factories & & & & & & \\
\hline
\end{tabular}

Note: All figures are based on the full sample of 130,278 people. 
Table 1.3

Summary Statistics

Variable

Obs. Mean

Std.
Dev.

Min.

Max.

TASTE for REVOLT?

$\begin{array}{ccccc}130,278 & 0.098 & 0.297 & 0 & 1 \\ 99,864 & 0.827 & 0.378 & 0 & 1 \\ 99,864 & 0.655 & 0.475 & 0 & 1 \\ 99,864 & 0.070 & 0.255 & 0 & 1 \\ 99,864 & 0.099 & 0.299 & 0 & 1 \\ 102 & 2.61 & 0.60 & 1 & 3 \\ 102 & 5.80 & 1.58 & 1 & 7 \\ 102 & 5.44 & 1.54 & 1 & 7 \\ 98 & 11,043 & 6,803 & 748 & 25,644\end{array}$

RELIGIOUS

- CHRISTIAN

- MUSLIM

- OTHER RELIGION

FREEDOM

POLITICAL RIGHTS

CIVIL LIBERTIES

GDP per CAPITA (raw level)

GDP per CAPITA (in logs)

98

9.04

0.85

6.62

10.15

$\Delta$ GDP per CAPITA (in logs)

97

$-3.7 e-3$

0.04

$-0.11$

0.10

INFLATION RATE (in logs)

97

2.56

1.63

$-1.19$

8.86

TRADE OPENNESS

97

0.36

0.28

0

1.19

PRIMARY EDUCATION

97

1.03

0.09

0.69

1.25

Note: These figures are based on World Values Survey data from the following 61 countries: Argentina, Armenia, Australia, Austria, Azerbaijan, Belgium, Bangladesh, Bulgaria, BosniaHerzegovina, Belarus, Brazil, Canada, Switzerland, Chile, China, Colombia, Czech Republic, East and Unified Germany, Denmark, Dominican Republic, Spain, Estonia, Finland, France, United Kingdom, Georgia, Ghana, Croatia, Hungary, India, Ireland, Iceland, Italy, Japan, South Korea, Lithuania, Latvia, Moldova, Mexico, Macedonia, Nigeria, The Netherlands, Norway, Pakistan, Peru, Philippines, Poland, Puerto Rico, Portugal, Russia, Slovak Republic, Slovenia, Sweden, Turkey, Taiwan, Ukraine, Uruguay, United States of America, Venezuela, Serbia (exYugoslavia), South Africa. The three waves of the WVS used were taken in 1981-84, 1990-92 and 1995-97. 


\section{Table 1.4a}

Revolutionary Tastes in Countries with more than 1 percent Muslims in the Sample

\begin{tabular}{|lcccc|}
\hline \hline Country & Freedom & $\begin{array}{c}\text { Percentage of all } \\
\text { people with a } \\
\text { Revolutionary Taste }\end{array}$ & $\begin{array}{c}\text { Percentage of } \\
\text { Muslims } \\
\text { in the Sample }\end{array}$ & $\begin{array}{c}\text { Percentage of } \\
\text { Muslims with a } \\
\text { Revolutionary Taste }\end{array}$ \\
\hline Australia & Free & 5.2 & 1.3 & 0 \\
Bulgaria 1997 & Free & 6.6 & 11.8 & 1.5 \\
Finland & Free & 2.2 & 2.5 & 0 \\
Slovenia & Free & 10.4 & 1.3 & 5.0 \\
South Africa 1996 & Free & 12.1 & 2.1 & 1.8 \\
Bulgaria 1990 & Partly Free & 22.1 & 6.6 & 3.9 \\
Bosnia-Herzeg. & Partly Free & 15.4 & 27.3 & 10.1 \\
Croatia & Partly Free & 4.8 & 1.2 & 0 \\
Georgia & Partly Free & 9.4 & 4.0 & 13.2 \\
Ghana & Partly Free & 13.3 & 5.3 & 0 \\
India & Partly Free & 14.5 & 8.5 & 12.9 \\
Macedonia & Partly Free & 12.4 & 24.3 & 31.9 \\
Nigeria & Partly Free & 28.1 & 24.8 & 25.7 \\
Russia & Partly Free & 13.9 & 2.6 & 9.6 \\
South Africa 1990 & Partly Free & 15.9 & 10.3 & 18.3 \\
Taiwan & Partly Free & 2.9 & 2.8 & 2.5 \\
Bangladesh & Partly Free & 10.8 & 85.9 & 10.5 \\
Pakistan & Partly Free & 29.1 & 81.9 & 28.7 \\
Turkey & Partly Free & 18.7 & 95.6 & 17.0 \\
China & Not Free & 5.2 & 1.3 & 7.7 \\
Serbia (ex-Yug.) & Not Free & 12.8 & 5.8 & 12.7 \\
South Africa 1982 & Not Free & 16.0 & 5.7 & 46.0 \\
Azerbaijan & Not Free & 23.5 & 91.6 & 24.9 \\
\hline \hline & & & & \\
\hline
\end{tabular}

\section{Table 1.4b}

Average Revolutionary Taste of Muslims by Country Freedom Status

\begin{tabular}{lccc|}
\hline \hline & \multicolumn{3}{c|}{ Freedom Status of Country } \\
\cline { 2 - 4 } Countries where... & Free & Partly Free & Not Free \\
\hline Muslims are the Majority & - & 18.7 & 24.9 \\
Muslims are a Minority & 1.7 & 11.6 & 22.1 \\
\hline \hline
\end{tabular}

Note: All numbers are expressed as percentages of the number of Muslims living in the country. 
Table 2.1

How the Taste for Revolt varies with Freedom and GDP across 61 nations, 1981 to 997.

\begin{tabular}{|c|c|c|c|c|c|c|}
\hline Dep. Variable: TASTE for REVOLT? & (1) & (2) & (3) & (4) & (5) & (6) \\
\hline Freedom & $\begin{array}{c}-0.032 * * \\
(3.54)\end{array}$ & $\begin{array}{c}-0.037 * * \\
(3.90)\end{array}$ & $\begin{array}{c}-0.035^{* *} \\
(3.42)\end{array}$ & $\begin{array}{c}-0.036 * * \\
(3.69)\end{array}$ & & \\
\hline Civil Liberties & & & & & $\begin{array}{c}-0.017 * * \\
(5.23)\end{array}$ & \\
\hline Political Rights & & & & & & $\begin{array}{c}-0.017 * * \\
(4.11)\end{array}$ \\
\hline GDP per capita & & $\begin{array}{l}-0.032 \\
(1.63)\end{array}$ & $\begin{array}{c}-0.035 \\
(1.53)\end{array}$ & $\begin{array}{c}-0.032 \\
(1.57)\end{array}$ & $\begin{array}{c}-6.7 e-4 \\
(0.03)\end{array}$ & $\begin{array}{l}0.004 \\
(0.20)\end{array}$ \\
\hline$\Delta$ GDP per capita & & & $\begin{array}{c}-0.201 * \\
(1.95)\end{array}$ & $\begin{array}{c}-0.277 * * \\
(2.46)\end{array}$ & $\begin{array}{c}-0.245^{*} \\
(2.14)\end{array}$ & $\begin{array}{l}0.014 \\
(0.11)\end{array}$ \\
\hline Personal Income Quintile - Second & & & & $\begin{array}{c}-0.004 \\
(1.26)\end{array}$ & $\begin{array}{c}-0.004 \\
(1.09)\end{array}$ & $\begin{array}{c}-0.004 \\
(1.27)\end{array}$ \\
\hline Third & & & & $\begin{array}{c}-0.009 * \\
(1.98)\end{array}$ & $\begin{array}{c}-0.008 \\
(1.85)\end{array}$ & $\begin{array}{c}-0.009 * \\
(1.93)\end{array}$ \\
\hline Fourth & & & & $\begin{array}{l}-0.012 * \\
(2.35)\end{array}$ & $\begin{array}{c}-0.012 * \\
(2.31)\end{array}$ & $\begin{array}{c}-0.013 * * \\
(2.43)\end{array}$ \\
\hline Fifth (top) & & & & $\begin{array}{c}-0.020 * * \\
(3.40)\end{array}$ & $\begin{array}{c}-0.020 * * \\
(3.42)\end{array}$ & $\begin{array}{c}-0.021 * * \\
(3.39)\end{array}$ \\
\hline Country Dummies & Yes & Yes & Yes & Yes & Yes & Yes \\
\hline Year Dummies & Yes & Yes & Yes & Yes & Yes & Yes \\
\hline Pseudo $R^{2}$ & 0.08 & 0.09 & 0.09 & 0.09 & 0.09 & 0.09 \\
\hline Observations & 130,278 & 124,327 & 123,558 & 105,411 & 105,411 & 105,411 \\
\hline
\end{tabular}

Notes: [1] All the regressions are Probits. [2] Marginal Probabilities are reported. Absolute values of tstatistics are in parentheses. [3] Bold-face denotes significant at the 10 percent level; Single-starred bold-face at the 5 per cent level; Double-starred bold face at the 1 percent level. [4] The baseline category for the relative income position of the individual is the first (or bottom) quintile. 
Table 2.2

How the Taste for Revolt varies with Freedom, GDP and Religion in 61 nations, 19811997.

\begin{tabular}{|c|c|c|c|c|c|c|}
\hline Dep. Variable: TASTE for REVOLT? & (1) & (2) & (3) & (4) & (5) & (6) \\
\hline Freedom & $\begin{array}{c}-0.032 * * \\
(3.71) \\
\end{array}$ & $\begin{array}{c}-0.031 * * \\
(3.78) \\
\end{array}$ & $\begin{array}{c}-0.020 * * \\
(1.64) \\
\end{array}$ & $\begin{array}{c}-0.027 * * \\
(2.94) \\
\end{array}$ & $\begin{array}{c}-0.033 * * \\
(3.75) \\
\end{array}$ & $\begin{array}{c}-0.032 * * \\
(4.67) \\
\end{array}$ \\
\hline GDP per capita & $\begin{array}{c}-0.032 \\
(1.72) \\
\end{array}$ & $\begin{array}{c}-0.033 \\
(1.76) \\
\end{array}$ & $\begin{array}{c}-0.035 \\
(1.74) \\
\end{array}$ & $\begin{array}{c}-0.038 \\
(1.89) \\
\end{array}$ & $\begin{array}{c}-0.031 \\
(1.67) \\
\end{array}$ & $\begin{array}{c}-0.035 \\
(1.88) \\
\end{array}$ \\
\hline$\Delta$ GDP per capita & $\begin{array}{c}-0.292^{* *} \\
(2.55)\end{array}$ & $\begin{array}{c}-0.291 * * \\
(2.61)\end{array}$ & $\begin{array}{c}-0.301 * * \\
(2.52)\end{array}$ & $\begin{array}{c}-0.271^{* *} \\
(2.87)\end{array}$ & $\begin{array}{c}-0.234 * \\
(1.94)\end{array}$ & $\begin{array}{c}-0.256 * * \\
(2.62)\end{array}$ \\
\hline Personal Income Quintile- Second & $\begin{array}{c}-0.004 \\
(1.25)\end{array}$ & $\begin{array}{l}-0.004 \\
(1.21)\end{array}$ & $\begin{array}{l}-0.004 \\
(1.24)\end{array}$ & $\begin{array}{c}-0.004 \\
(1.27)\end{array}$ & $\begin{array}{l}-0.004 \\
(1.25)\end{array}$ & $\begin{array}{c}-0.004 \\
(1.23)\end{array}$ \\
\hline Third & $\begin{array}{c}-0.010 * \\
(2.41) \\
\end{array}$ & $\begin{array}{c}-0.010^{*} \\
(2.34) \\
\end{array}$ & $\begin{array}{c}-0.010 * \\
(2.40) \\
\end{array}$ & $\begin{array}{c}-0.009 * \\
(2.37) \\
\end{array}$ & $\begin{array}{c}-0.010 * \\
(2.41)\end{array}$ & $\begin{array}{c}-0.010 * \\
(2.37) \\
\end{array}$ \\
\hline Fourth & $\begin{array}{c}-0.012 * * \\
(2.43)\end{array}$ & $\begin{array}{c}-0.012 * \\
(2.32)\end{array}$ & $\begin{array}{c}-0.012 * \\
(2.42)\end{array}$ & $\begin{array}{c}-0.012 * * \\
(2.43)\end{array}$ & $\begin{array}{c}-0.012 * * \\
(2.44)\end{array}$ & $\begin{array}{c}-0.012 * \\
(2.28)\end{array}$ \\
\hline Fifth (top) & $\begin{array}{c}-0.020 * * \\
(3.59)\end{array}$ & $\begin{array}{c}-0.019 * * \\
(3.54)\end{array}$ & $\begin{array}{c}-0.020 * * \\
(3.59)\end{array}$ & $\begin{array}{c}-0.019 * * \\
(3.58)\end{array}$ & $\begin{array}{c}-0.020 * * \\
(3.60)\end{array}$ & $\begin{array}{c}-0.019 * * \\
(3.51)\end{array}$ \\
\hline Religious & $\begin{array}{c}-0.030 * * \\
(5.24) \\
\end{array}$ & & $\begin{array}{l}0.010 \\
(0.46) \\
\end{array}$ & & $\begin{array}{c}0.030 * * \\
(5.39) \\
\end{array}$ & \\
\hline Christian & & $\begin{array}{c}-0.034 * * \\
(6.13)\end{array}$ & & $\begin{array}{l}0.004 \\
(0.25)\end{array}$ & & $\begin{array}{c}-0.034 * * \\
(6.27) \\
\end{array}$ \\
\hline Muslim & & $\begin{array}{c}-0.007 \\
(0.38) \\
\end{array}$ & & $\begin{array}{l}0.188 * \\
(2.23)\end{array}$ & & $\begin{array}{c}-0.009 \\
(0.51) \\
\end{array}$ \\
\hline Other Religion & & $\begin{array}{l}-0.005 \\
(0.60)\end{array}$ & & $\begin{array}{l}-0.033 \\
(1.87)\end{array}$ & & $\begin{array}{l}-0.008 \\
(1.07)\end{array}$ \\
\hline Religious * Freedom & & & $\begin{array}{l}-0.015 \\
(1.82)\end{array}$ & & & \\
\hline Christian $*$ Freedom & & & & $\begin{array}{c}-0.015 * \\
(2.25) \\
\end{array}$ & & \\
\hline Muslim * Freedom & & & & $\begin{array}{c}-0.062 * * \\
(2.58)\end{array}$ & & \\
\hline Other Religion * Freedom & & & & $\begin{array}{l}0.014 \\
(1.46) \\
\end{array}$ & & \\
\hline Religious $* \Delta$ GDP per capita & & & & & $\begin{array}{l}-0.062 \\
(0.89)\end{array}$ & \\
\hline Christian* $\Delta$ GDP per capita & & & & & & $\begin{array}{l}0.015 \\
(0.18)\end{array}$ \\
\hline Muslim* $\Delta$ GDP per capita & & & & & & $\begin{array}{l}-0.274 \\
(0.72) \\
\end{array}$ \\
\hline Other Relig. $* \Delta G D P$ per capita & & & & & & $\begin{array}{l}-0.297 \\
(1.87)\end{array}$ \\
\hline Country Dummies & Yes & Yes & Yes & Yes & Yes & Yes \\
\hline Year Dummies & Yes & Yes & Yes & Yes & Yes & Yes \\
\hline Pseudo $\mathrm{R}^{2}$ & 0.08 & 0.08 & 0.08 & 0.09 & 0.08 & 0.08 \\
\hline Observations & 99,864 & 99,864 & 99,864 & 99,864 & 99,864 & 99,864 \\
\hline
\end{tabular}

Notes: [1] All the regressions are Probits. [2] Marginal Probabilities are reported. Absolute values of tstatistics are in parentheses. [3] Bold-face denotes significant at the 10\% level; Single-starred bold-face at the $5 \%$ level; Double-starred bold face at the 1\% level. [4] The baseline category for the relative income position of the individual is the First (bottom) quintile and for the religion variables is declaring one-self as belonging to no religious denomination. 
Table 2.3

How the Taste for Revolt varies with Freedom, GDP and Religion in 61 Nations, 1981 to 1997: Adding More Controls.

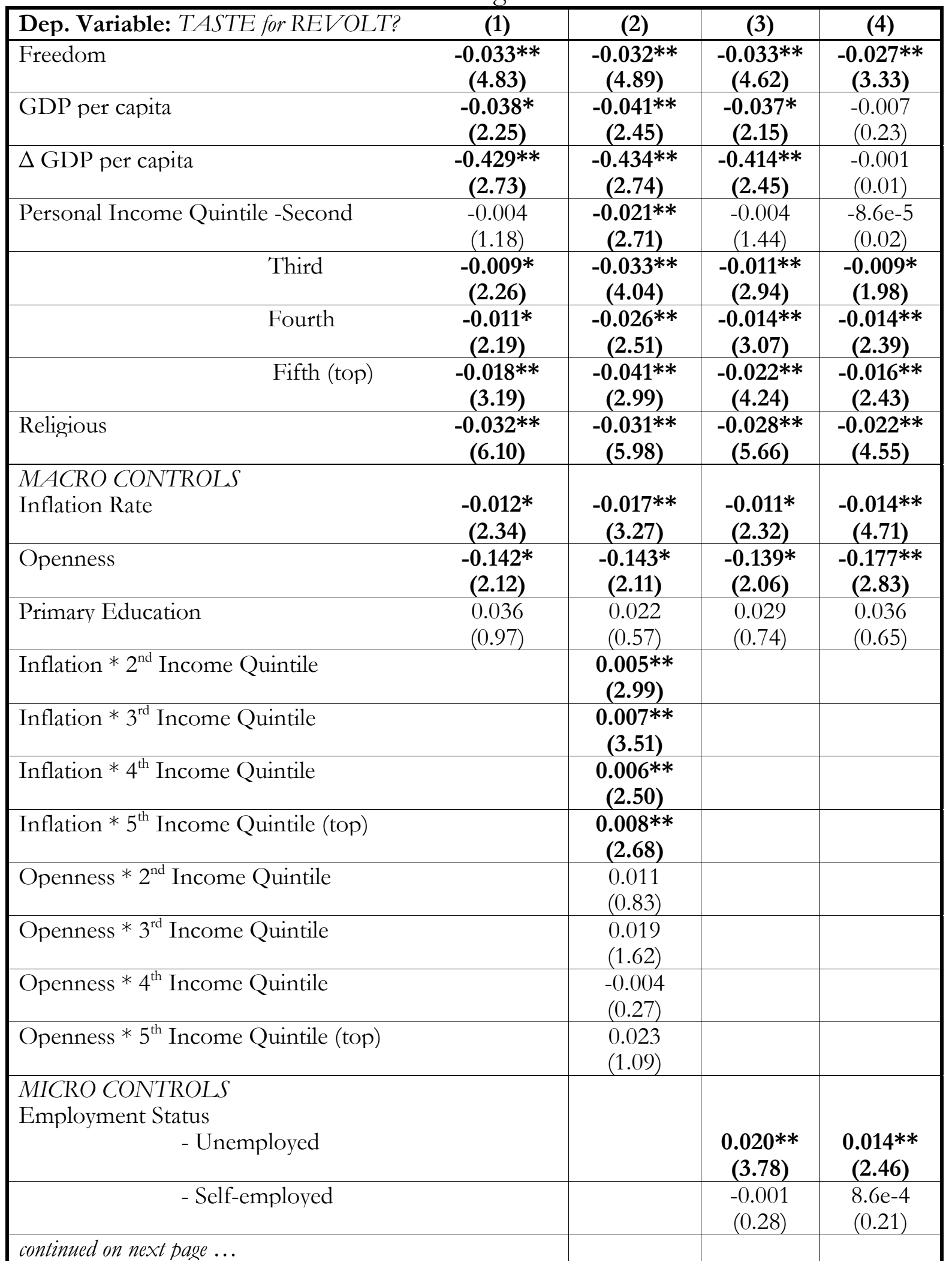




\begin{tabular}{|c|c|c|c|c|}
\hline $\begin{array}{l}\text {.. continued from previous page } \\
\text { Dep. Var: TASTE for REVOLT? }\end{array}$ & (1) & (2) & (3) & (4) \\
\hline - Retired & & & $\begin{array}{c}-0.025 * * \\
(5.93)\end{array}$ & $\begin{array}{l}-0.006 \\
(1.15)\end{array}$ \\
\hline - Student & & & $\begin{array}{c}0.017 * * \\
(4.02)\end{array}$ & $\begin{array}{l}0.008 \\
(0.76)\end{array}$ \\
\hline - Housewife & & & $\begin{array}{c}-0.019 * * \\
(3.93)\end{array}$ & $\begin{array}{l}0.003 \\
(0.60)\end{array}$ \\
\hline - Other & & & $\begin{array}{l}0.012 \\
(1.25)\end{array}$ & $\begin{array}{l}0.017 \\
(1.80)\end{array}$ \\
\hline Marital status - Married & & & & $\begin{array}{c}-0.020^{* *} \\
(2.75)\end{array}$ \\
\hline - Divorced & & & & $\begin{array}{c}-0.006 \\
(0.67)\end{array}$ \\
\hline - Separated & & & & $\begin{array}{r}-0.003 \\
(0.38)\end{array}$ \\
\hline - Widowed & & & & $\begin{array}{c}-0.017^{*} \\
(2.34)\end{array}$ \\
\hline - Middle (26-50 years old) & & & & $\begin{array}{c}-0.007 \\
(1.68)\end{array}$ \\
\hline - Old (> 50 years old $)$ & & & & $\begin{array}{c}-0.020^{* *} \\
(4.03)\end{array}$ \\
\hline Male & & & & $\begin{array}{c}0.019 * * \\
(5.10)\end{array}$ \\
\hline Age Finished School: $12-14$ years old & & & & $\begin{array}{c}-0.004 \\
(0.70)\end{array}$ \\
\hline $15-18$ years old & & & & $\begin{array}{c}-0.002 \\
(0.32)\end{array}$ \\
\hline 19-21 years old & & & & $\begin{array}{l}7.3 \mathrm{e}-5 \\
(0.01)\end{array}$ \\
\hline$>21$ years old & & & & $\begin{array}{c}-0.006 \\
(0.81)\end{array}$ \\
\hline Number of Children: 1 & & & & $\begin{array}{l}0.019 * \\
(2.22)\end{array}$ \\
\hline 2 & & & & $\begin{array}{l}0.012 \\
(1.29)\end{array}$ \\
\hline$>3$ & & & & $\begin{array}{l}0.013 \\
(1.41)\end{array}$ \\
\hline Country Dummies & Yes & Yes & Yes & Yes \\
\hline Year Dummies & Yes & Yes & Yes & Yes \\
\hline Pseudo R ${ }^{2}$ & 0.08 & 0.08 & 0.09 & 0.10 \\
\hline Observations & 98,963 & 98,963 & 98,281 & 62,674 \\
\hline
\end{tabular}

Notes: [1] All regressions are Probits. Marginal Probabilities are reported. Absolute values of t-statistics in parentheses. [3] Bold-face denotes significant at the 10\% level; Single-starred bold at the 5\% level; Double-starred bold at the 1\% level. [4] The baseline category for the individual income position is the First (or bottom) quintile, for Religious is declaring one-self as belonging to no religious denomination, for Employment Status is a working employee, for Marital Status is single, for Age is young, for Age Finished School is to have stopped school before being 12 years old, and for Number of cbildren is no children. 


\section{Survey Descriptions}

\section{World Values Survey and European Values Survey (1981-1984, 1990-1992, 1995-1997)}

The Combined World Values Survey is produced by the Institute for Social Research, Ann Arbor, MI, USA. The series is designed to enable a cross-national comparison of values and norms on a wide variety of norms and to monitor changes in values and attitudes across the globe. Both national random and quota sampling were used. All of the surveys were carried out through face-to-face interviews, with a sampling universe consisting of all adult citizens, aged 18 and older, across over 60 nations around the world.

These surveys are being expanded to provide a more complete cross-sectional, as well as time series, dimension. The 1981-83 survey covered 22 independent countries plus surveys in Northern Ireland and Tambov oblast of the Russian republic; the 1990-93 survey covered 42 independent countries plus surveys in Northern Ireland, and Greater Moscow; the 1995-97 survey covered 53 independent countries, plus surveys in Puerto Rico, Tambov oblast, Montenegro, the Andalusian, Basque, Galician and Valencian regions of Spain and a pilot survey in Ghana. In all, 64 independent countries have been surveyed in at least one wave of this investigation (counting East Germany as an independent country, which it was when first surveyed). These countries include almost 80 percent of the world's population. A fourth wave of surveys is being carried out in 1999-2000.

The full set of countries covered by the survey is as follows: Argentina, Armenia, Australia, Austria, Azerbaijan, Belgium, Bangladesh, Bulgaria, Bosnia-Herzegovina, Belarus, Brazil, Canada, Switzerland, Chile, China, Colombia, Czech Republic, East and Unified Germany, Denmark, Dominican Republic, Spain, Estonia, Finland, France, United Kingdom, Georgia, Ghana, Croatia, Hungary, India, Ireland, Northern Ireland, Iceland, Italy, Japan, South Korea, Lithuania, Latvia, Madagascar, Mexico, Macedonia, Mongolia, The Netherlands, Norway, Pakistan, Peru, Philippines, Poland, Puerto Rico, Portugal, Russia, Slovak Republic, Slovenia, Sweden, Turkey, Taiwan, Ukraine, Uruguay, United States of America, Venezuela, South Africa, Moscow, Tambov oblast, Montenegro, the Andalusian, Basque, Galician and Valencian regions in Spain, Nigeria, Romania, Moldova and Serbia (ex- Yugoslavia).

\section{Freedom House Survey}

Freedom in the World is an institutional effort by the Freedom House organization to monitor the progress and decline of political rights and civil liberties in 192 nations and 60 related and disputed territories. The annual survey is a year-long effort produced by regional experts, consultants, and human rights specialists. Throughout the year, Freedom House personnel regularly conduct fact-finding missions to gain more indepth knowledge of the political transformations affecting the countries studied, meeting a cross-section of political parties and associations, human rights monitors, religious figures, representatives of both the private sector and trade union movement, academics and journalists. Since 1972, Freedom House has published an annual assessment of state of freedom by assigning each country and territory the status of "Free", "Partly Free", or "Not Free" by averaging their political rights and civil liberties ratings. First, political rights and civil liberties are rated separately on a seven-category scale, 1 representing the most free and 7 the least free. A country is assigned to a particular numerical category based on responses to the checklist and the judgments of the Survey team at Freedom House. To answer the political rights questions, Freedom House considers the extent to which the system offers the voter the chance to make a free choice among candidates, and to what extent the candidates are chosen independently of the state. In particular, it follows a "checklist" of Political Rights and Civil Liberties, although it recognizes that formal electoral procedures are not the only factors that determine the real distribution of power. The more that people suffer under domination by unelected forces such as the military or the king, the less chance the country has of receiving credit for selfdetermination in the Survey. 
The Political Rights Checklist includes:

1. Is the head of state and/or head of government or other chief authority elected through free and fair elections?

2. Are the legislative representatives elected through free and fair elections?

3. Are there fair electoral laws, equal campaigning opportunities, fair polling, and honest tabulation of ballots?

4. Are the voters able to endow their freely elected representatives with real power?

5. Do the people have the right to organize in different political parties or other competitive political groupings of their choice, and is the system open to the rise and fall of these competing parties or groupings?

6. Is there a significant opposition vote, de facto opposition power, and a realistic possibility for the opposition to increase its support or gain power through elections?

7. Are the people free from domination by the military, foreign powers, totalitarian parties, religious hierarchies, economic oligarchies, or any other powerful group?

8. Do cultural, ethnic, religious, and other minority groups have reasonable self-determination, selfgovernment, autonomy, or participation through informal consensus in the decision-making process?

9. For traditional monarchies that have no parties or electoral process, does the system provide for consultation with the people, encourage discussion of policy, and allow the right to petition the ruler?

10. Is the government or occupying power deliberately changing the ethnic composition of a country or territory so as to destroy a culture or tip the political balance in favor of another group?

\section{Political Rights Ratings}

Political Rights are rated on a scale from 1 to 7 . Countries and territories which receive a rating of 1 for political rights come closest to the ideals suggested by the checklist questions, beginning with free and fair elections. Those who are elected rule, there are competitive parties or other political groupings, and the opposition plays an important role and has actual power. Citizens enjoy self-determination or an extremely high degree of autonomy (in the case of territories), and minority groups have reasonable self-government or can participate in the government through informal consensus. Countries and territories rated 2 in political rights are less free than those rated 1. Such factors as gross political corruption, violence, political discrimination against minorities, and foreign or military influence on politics may be present and weaken the quality of democracy. The same conditions which undermine freedom in countries and territories with a rating of 2 may also weaken political rights in those with a rating of 3, 4, or 5. Other damaging elements can include civil war, heavy military involvement in politics, lingering royal power, unfair elections, and one-party dominance. However, states and territories in these categories may still enjoy some elements of political rights, including the freedom to organize quasi-political groups, reasonably free referenda, or other significant means of popular influence on government. Countries and territories with political rights rated 6 have systems ruled by military juntas, one-party dictatorships, religious hierarchies, or autocrats. These regimes may allow only a minimal manifestation of political rights, such as competitive local elections or some degree of representation or autonomy for minorities. Some countries and territories rated 6 are in the early or aborted stages of democratic transition. For countries and territories with a rating of 7 , political rights are absent or virtually nonexistent due to the extremely oppressive nature of the regime or severe oppression in combination with civil war. States and territories in this group may also be marked by extreme violence or warlord rule which dominates political power in the absence of an authoritative, functioning central government. 
The Civil Liberties Checklist includes:

A. Freedom of Expression and Belief

1. Are there free and independent media and other forms of cultural expression? (Note: in cases where the media are state-controlled but offer pluralistic points of view, the Survey gives the system credit.)

2. Are there free religious institutions and is there free private and public religious expression?

B. Association and Organizational Rights

1. Is there freedom of assembly, demonstration, and open public discussion?

2. Is there freedom of political or quasi-political organization? (Note: this includes political parties, civic organizations, ad hoc issue groups, etc.)

3. Are there free trade unions and peasant organizations or equivalents, and is there effective collective bargaining? Are there free professional and other private organizations?

C. Rule of Law and Human Rights

1. Is there an independent judiciary?

2. Does the rule of law prevail in civil and criminal matters? Is the population treated equally under the law? Are police under direct civilian control?

3. Is there protection from political terror, unjustified imprisonment, exile, or torture, whether by groups that support or oppose the system? Is there freedom from war and insurgencies? (Note: freedom from war and insurgencies enhances the liberties in a free society, but the absence of wars and insurgencies does not in and of itself make a not free society free.)

4. Is there freedom from extreme government indifference and corruption?

D. Personal Autonomy and Economic Rights

1. Is there open and free private discussion?

2. Is there personal autonomy? Does the state control travel, choice of residence, or choice of employment? Is there freedom from indoctrination and excessive dependency on the state?

3. Are property rights secure? Do citizens have the right to establish private businesses? Is private business activity unduly influenced by government officials, the security forces, or organized crime?

4. Are there personal social freedoms, including gender equality, choice of marriage partners, and size of family?

5. Is there equality of opportunity, including freedom from exploitation by or dependency on landlords, employers, union leaders, bureaucrats, or other types of obstacles to a share of legitimate economic gains?

\section{Civil Liberties Ratings}

When analyzing the civil liberties checklist, Freedom House does not mistake constitutional guarantees of human rights for those rights in practice. Countries and territories which receive a rating of 1 come closest to the ideals expressed in the civil liberties checklist, including freedom of expression, assembly, association, and religion. They are distinguished by an established and generally equitable system of rule of law and are comparatively free of extreme government indifference and corruption. Countries and territories with this rating enjoy free economic activity and tend to strive for equality of opportunity. States and territories with a rating of 2 have deficiencies in three or four aspects of civil liberties, but are still relatively free. Countries and territories which have received a rating of 3, 4, or 5 range from those that are in at least partial compliance with virtually all checklist standards to those with a combination of high or medium scores for some questions and low or very low scores on other questions. The level of oppression increases at each successive rating level, particularly in the areas of censorship, political terror, and the prevention of free association. There are also many cases in which groups opposed to the state engage in political terror that undermines other freedoms. Therefore, a poor rating for a country is not necessarily a comment on the intentions of the government, but may reflect real restrictions on liberty caused by nongovernmental terror. Countries and territories rated 6 are characterized by a few partial rights, such as some religious and social freedoms, some 
highly restricted private business activity, and relatively free private discussion. In general, people in these states and territories experience severely restricted expression and association, and there are almost always political prisoners and other manifestations of political terror. States and territories with a rating of 7 have virtually no freedom. An overwhelming and justified fear of repression characterizes these societies.

Almost without exception in the Survey, countries and territories have ratings in political rights and civil liberties that are within two ratings numbers of each other. A society that does not have free individual and group expression in nonpolitical matters is not likely to make an exception for political ones.

\section{Free, Partly Free, Not Free}

The Survey then assigns each country and territory the status of "Free," "Partly Free," or "Not Free" by averaging their political rights and civil liberties ratings. Those whose ratings average 1-2.5 are generally considered "Free," 2.5-5.5 "Partly Free," and 5.5-7 "Not Free." The dividing line between "Partly Free" and "Not Free" usually falls within the group whose ratings numbers average 5.5. For example, countries that receive a rating of 6 for political rights and 5 for civil liberties, or a 5 for political rights and a 6 for civil liberties, could be either "Partly Free" or "Not Free." The total number of raw points derived from the original checklist is the definitive factor which determines the final status. It should be emphasized that the "Free," "Partly Free," and "Not Free" labels are highly simplified terms that each cover a broad third of the available raw points. Therefore, countries and territories within each category, especially those at either end of each category, can have quite different human rights situations. In order to see the distinctions within each category, one should examine a country or territory's political rights and civil liberties ratings.

More information on the methodology can be found on the web-site:

http://www.freedomhouse.org/research/freeworld/2000/methodology.htm 


\section{Data Definitions}

TASTE for REVOLT?: A dummy variable that equals 1 when the survey respondent answers that "The entire way our society is organised must be radically changed by revolutionary action", and equals 0 when the respondent answers that either "Our society must be gradually improved by reforms" or "Our present society must be valiantly defended against all subversive forces". The source is the World Values Survey (1980-1997).

FREEDOM: An index measured on a one-to-three discrete scale with the lowest value, 1, being assigned to "Not Free" countries and the highest value, 3, assigned to "Free" countries. The index is a composite measure obtained by averaging the two separate indices, Political Rights and Civil Liberties. For further information, see the Appendix (from the Freedom House organization).

POLITICAL RIGHTS: As index whose lowest value, 1, is assigned to countries with the least political rights and the highest value, 7 , is assigned to the countries with the most. Countries are assigned to a particular numerical category based on responses to the checklist and the judgments of the Survey team at Freedom House. To answer the political rights questions, the extent to which the system offers the voter the chance to make a free choice among candidates, and to what extent the candidates are chosen independently of the state, is considered. For more information about the "checklist" of political rights, see the Appendix.

CIVIL LIBERTIES: As index whose lowest value, 1, is assigned to countries with the least civil liberties and the highest value, 7 , is assigned to the countries with the most. Countries are assigned to a particular numerical category based on responses to the checklist and the judgments of the Survey team at Freedom House. To answer the civil liberties questions, the extent of freedom of expression, assembly, association, and religion are considered. These are distinguished by an established and generally equitable system of rule of law and are comparatively free of extreme government indifference and corruption. For more information about the checklist of civil liberties, see the Appendix.

GDP per capita: GDP per capita, with Purchasing Power Parity adjustment, in constant 1992 US \$, and measured in logs. The source is the World Development Indicators of the World Bank.

$\triangle$ GDP per capita: The first difference of GDP per capita (with PPP adjustment, in constant 1992 US\$). The source is the World Development Indicators of the World Bank.

INCOME QUINTILE: This heading refers to a set of 4 dummy variables which take the value 1 depending on which income quintile the respondent's family income belongs to. The base category is the lowest income quintile (from World Values Survey).

RELIGIOUS: A dummy variable that equals 1 when the survey respondent answers yes to the question "Do you belong to a religious denomination? If yes, which one?". The specific categories of religion listed in the remainder of the question were "1. Roman Catholic 2. Protestant 3. Orthodox (Russian/Greek) 4. Jews 5. Muslim 6. Hindu 7. Buddhist 8. Other". The base 
category is people who answer " 0 . Not a member" or "No religious denomination" (from World Values Survey).

CHRISTIAN: A dummy variable that equals 1 when the survey respondent declares herself as belonging to one the following three religious groups: "1. Roman Catholic 2. Protestant 3. Orthodox (Russian/Greek)"”.

MUSLIM: A dummy variable that equals 1 when the survey respondent declares herself as belonging to "5. Muslim" (from World Values Survey).

OTHER RELIGION: A dummy variable that equals 1 when the survey respondent declares herself as belonging one of the following religious groups "4. Jews 5. Muslim 6. Hindu 7. Buddhist 8. Other" (from World Values Survey).

INFLATION RATE: The inflation rate, as measured by the annual rate of change in consumer prices, measured in logs. The source is the World Development Indicators of the World Bank.

OPENNESS: It is measured as the absolute sum of imports and exports as a ratio to GDP. The source is the World Development Indicators of the World Bank.

PRIMARY EDUCATION: Gross enrolment ratio is the ratio of total enrolment, regardless of age, to the population of the age group that officially corresponds to the level of education shown. Primary education provides children with basic reading, writing, and mathematics skills along with an elementary understanding of such subjects as history, geography, natural science, social science, art, and music. The source is the World Development Indicators of the World Bank.

EMPLOYMENT STATUS: A set of dummy variables taking the value 1 depending on the respondent's employment status: "Unemployed", "Self-employed", "Retired", "Student", "Housewife" or "Other". The base category is "Employed" (from World Values Survey).

MARITAL STATUS: A set of dummy variables taking the value 1 depending on the respondent's marital status: "Married", "Divorced", "Separated" or "Widowed". The base category is "Never Married".

$A G E$ : A set of dummy variables corresponding to the respondent's age: "Middle" which corresponds to 26-50 years old, "Old" which corresponds to greater than 50 years old. The base category is "Young" which corresponds to less than 26 years old (from World Values Survey).

MALE: A dummy variable taking the value 1 if the respondent is male and 0 otherwise (from World Values Survey).

AGE FINISHED SCHOOL: This heading refers to a set of dummy variables which take the value 1 depending on the age at which the respondent finished full-time education: up to "12-14 years old", "15-18 years old", "19-21 years old" or up to "more than 21 years old". The base category is education up to, but not including, 12 years old (from World Values Survey).

NUMBER OF CHILDREN: The number of children living in the household: 1, 2 or more than 2. The base category is zero (from World Values Survey). 
Data summary

\begin{tabular}{|c|c|c|c|}
\hline Country & Year & Freedom Status & $\begin{array}{l}\text { Proportion of people with } \\
\text { a Revolutionary Preference }\end{array}$ \\
\hline Argentina & 1984 & Free & 12.4 \\
\hline Argentina & 1991 & Free & 7.5 \\
\hline Argentina & 1995 & Free & 5.1 \\
\hline Armenia & 1997 & Partly Free & 16.0 \\
\hline Australia & 1981 & Free & 4.4 \\
\hline Australia & 1995 & Free & 5.7 \\
\hline Austria & 1990 & Free & 2.2 \\
\hline Azerbaijan & 1996 & Not Free & 23.5 \\
\hline Bangladesh & 1996 & Partly Free & 10.8 \\
\hline Belarus & 1996 & Not Free & 3.7 \\
\hline Belgium & 1981 & Free & 6.7 \\
\hline Belgium & 1990 & Free & 4.1 \\
\hline Bosnia-Herzeg. & 1998 & Partly Free & 15.4 \\
\hline Brazil & 1991 & Free & 16.4 \\
\hline Brazil & 1997 & Partly Free & 18.1 \\
\hline Britain & 1981 & Free & 4.8 \\
\hline Britain & 1990 & Free & 5.1 \\
\hline Bulgaria & 1990 & Partly Free & 22.1 \\
\hline Bulgaria & 1997 & Free & 6.6 \\
\hline Canada & 1981 & Free & 4.8 \\
\hline Canada & 1990 & Free & 4.7 \\
\hline Chile & 1990 & Free & 5.3 \\
\hline Chile & 1996 & Free & 5.9 \\
\hline China & 1990 & Not Free & 5.2 \\
\hline Colombia & 1997 & Partly Free & 7.1 \\
\hline Croatia & 1995 & Partly Free & 4.8 \\
\hline Czech Republic & 1990 & Free & 44.9 \\
\hline Denmark & 1981 & Free & 4.2 \\
\hline Denmark & 1990 & Free & 1.6 \\
\hline Dominican Rep. & 1996 & Partly Free & 12.6 \\
\hline East Germany & 1990 & Free & 12.5 \\
\hline East Germany & 1997 & Free & 6.1 \\
\hline Estonia & 1996 & Free & 2.9 \\
\hline Finland & 1990 & Free & 2.8 \\
\hline Finland & 1996 & Free & 1.8 \\
\hline France & 1981 & Free & 8.6 \\
\hline France & 1990 & Free & 4.3 \\
\hline Georgia & 1996 & Partly Free & 9.4 \\
\hline Ghana & 1995 & Partly Free & 13.3 \\
\hline Hungary & 1990 & Free & 6.2 \\
\hline Iceland & 1981 & Free & 1.8 \\
\hline Iceland & 1990 & Free & 3.2 \\
\hline
\end{tabular}




\begin{tabular}{|c|c|c|c|}
\hline \multicolumn{3}{|c|}{... continued from previous page } & \multirow[b]{2}{*}{$\begin{array}{l}\text { Proportion of people with } \\
\text { a Revolutionary Preference }\end{array}$} \\
\hline Country & Year & Freedom Status & \\
\hline India & 1990 & Free & 14.0 \\
\hline India & 1996 & Partly Free & 15.3 \\
\hline Ireland & 1981 & Free & 4.4 \\
\hline Ireland & 1990 & Free & 3.7 \\
\hline Italy & 1981 & Free & 7.9 \\
\hline Italy & 1990 & Free & 7.1 \\
\hline Japan & 1981 & Free & 3.1 \\
\hline Japan & 1990 & Free & 2.1 \\
\hline Japan & 1995 & Free & 3.5 \\
\hline Latvia & 1996 & Free & 10.9 \\
\hline Lithuania & 1996 & Free & 9.7 \\
\hline Macedonia & 1997 & Partly Free & 12.4 \\
\hline Mexico & 1981 & Partly Free & 12.0 \\
\hline Mexico & 1990 & Partly Free & 16.5 \\
\hline Mexico & 1996 & Partly Free & 12.8 \\
\hline Moldova & 1996 & Partly Free & 10.2 \\
\hline Netherlands & 1981 & Free & 3.4 \\
\hline Netherlands & 1990 & Free & 1.9 \\
\hline Nigeria & 1990 & Partly Free & 28.1 \\
\hline Nigeria & 1995 & Not Free & 31.6 \\
\hline Norway & 1982 & Free & 2.0 \\
\hline Norway & 1990 & Free & 2.4 \\
\hline Norway & 1996 & Free & 2.7 \\
\hline Pakistan & 1997 & Partly Free & 29.1 \\
\hline Peru & 1996 & Partly Free & 8.2 \\
\hline Philippines & 1996 & Free & 22.5 \\
\hline Poland & 1989 & Partly Free & 22.9 \\
\hline Poland & 1997 & Free & 8.9 \\
\hline Portugal & 1990 & Free & 4.7 \\
\hline Russia & 1991 & Partly Free & 17.2 \\
\hline Russia & 1995 & Partly Free & 10.9 \\
\hline Serbia & 1996 & Not Free & 12.8 \\
\hline Slovakia & 1990 & Free & 37.3 \\
\hline Slovenia & 1992 & Free & 14.3 \\
\hline Slovenia & 1995 & Free & 7.1 \\
\hline South Africa & 1982 & Not Free & 16.0 \\
\hline South Africa & 1990 & Partly Free & 15.9 \\
\hline South Africa & 1996 & Free & 12.1 \\
\hline South Korea & 1982 & Partly Free & 22.3 \\
\hline South Korea & 1990 & Free & 7.3 \\
\hline South Korea & 1996 & Free & 12.5 \\
\hline Spain & 1981 & Free & 7.9 \\
\hline Spain & 1990 & Free & 4.5 \\
\hline Spain & 1995 & Free & 4.6 \\
\hline
\end{tabular}




\begin{tabular}{|c|c|c|c|}
\hline \multicolumn{4}{|c|}{... continued from previous page } \\
\hline Country & Year & Freedom Status & $\begin{array}{l}\text { Proportion of people with } \\
\text { a Revolutionary Preference }\end{array}$ \\
\hline Sweden & 1982 & Free & 4.3 \\
\hline Sweden & 1990 & Free & 6.1 \\
\hline Sweden & 1996 & Free & 4.4 \\
\hline Switzerland & 1996 & Free & 6.6 \\
\hline Taiwan & 1995 & Partly Free & 2.9 \\
\hline Turkey & 1990 & Partly Free & 13.8 \\
\hline Turkey & 1996 & Partly Free & 21.2 \\
\hline Ukraine & 1996 & Partly Free & 8.7 \\
\hline Uruguay & 1996 & Free & 8.0 \\
\hline USA & 1982 & Free & 5.0 \\
\hline USA & 1990 & Free & 6.5 \\
\hline USA & 1995 & Free & 4.8 \\
\hline Venezuela & 1996 & Free & 11.4 \\
\hline West Germany & 1981 & Free & 2.5 \\
\hline West Germany & 1990 & Free & 1.7 \\
\hline West Germany & 1997 & Free & 2.3 \\
\hline
\end{tabular}




\section{References}

Acemoglu, D. and J. Robinson (2000) "Why Did the West Extend the Franchise? Democracy, Inequality and Growth in Historical Perspective", Quarterly Journal of Economics, November, 115: 1167-99.

Acemoglu, D. and J. Robinson (2001) "A Theory of Political Transitions", American Economic Review, September, 91: 938-63.

Alesina, A. and E. La Ferrara (2000), "Preferences for Redistribution in the Land of Opportunity," mimeo.

Alesina, A. and R. Perotti (1996) "Income Distribution, Political Instability, and Investment", European Economic Review 40(6): 1203-1228.

Alesina, A., S. Özler, N. Roubini and P. Swagel (1996) "Political Instability and Economic Growth", Journal of Economic Growth 1(June): 189-211.

Boeri, T., A. Borsch-Supan and G. Tabellini (2001) "Would you Like to Shrink the Welfare State?", The Opinions of European Citizens, Economic Policy, 16, 32.

Clark, A. and A. Oswald (1994). "Unhappiness and Unemployment", Economic Journal, 104, 648-659.

Coleman, J. (1990). Foundations of Social Theory, MA: Harvard University Press.

Collier, P. and A. Hoeffler (2000) "Greed and Grievance in Civil War", World Bank Policy Research Paper \#2355.

Cummings, R., D. Brookshire and W. Schulze, eds. (1986) Valuing Environment Goods, Totawa, NJ: Rowman \& Allanheld.

Deininger, Klaus and Lyn Squire (1996) “A New Data Set Measuring Income Inequality", World Bank Economic Review, 10 (3): 565-591.

Di Tella, R. and A. Ades (1999) "National Champions and Corruption: Some Unpleasant Interventionist Arithmetic", Economic Journal, 107 (July), 1023-1042.

Di Tella, R., R. MacCulloch and A. Oswald (2001) "Preferences over Inflation and Unemployment: Evidence from Happiness Surveys", American Economic Review, 91 (1), 335-42.

Doyle, Michael W. and Nicholas Sambanis. (2000) "International Peacebuilding: A Theoretical and Quantitative Analysis", American Political Science Review 94(4): 779-802.

Easterlin, R. (1974) "Does Economic Growth Improve the Human Lot? Some Empirical Evidence." In Nations and Households in Economic Growth: Essays in Honour of Moses Abramovitr, (ed. P. A. David and M. W. Reder). New York and London: Academic Press.

Elbadawi Ibrahim and Nicholas Sambanis. (2002) How Much War Will We See? Explaining the Prevalence of Civil War. Journal of Conflict Resolution, 46(3): 307-334.

Esty, Daniel C., Jack Goldstone, Ted Robert Gurr, Pamela T. Surko, Alan N. Unger, and Robert S. Chen (1998) The State Failure Task Force Report: Phase II Findings. (McLean, VA: Science Applications International Corporation).

Fearon, J. and D. Laitin (2001) "Ethnicity, Insurgency and Civil War", Paper prepared for the Annual Meeting of the American Political Science Association, San Francisco, CA. 
Fording, R. (1997) "The Conditional Effect of Violence as a Political Tactic: Mass Insurgency,

Welfare Generosity, and Electoral Context in the American States", American Journal of Political Science, 41(1): 1-29.

Francisco, R. (1993) "Theories of Protest and the Revolutions of 1989", American Journal of Political Science, 37(3): 663-680.

Frey, B. and F. Schneider (1978). "An Empirical Study of Politico-Economic Interaction in the US", Review of Economics and Statistics, 60(2): 174-183.

Garfinkel, M. and G. Skaperdas (1996) The Political Economy of Conflict and Appropriation, edited, New York: Cambridge University Press.

Grossman, H. (1991) "A General Equilibrium Model of Insurrections", American Economic Review, 81(4): 912-921.

Grossman, H. (1994) "Production, Appropriation and Land Reform", American Economic Review, 84(June): 705-712.

Grossman, H. (1999) "Kleptocracy and revolutions", Oxford Economic Papers, 51: 267-283.

Gurr. T. (1970) Why Men Rebel?, Princeton, NJ: Princeton University Press.

Gurr, T. and W. Moore (1997) "Ethnopolitical Rebellion: A Cross-Sectional Analysis of the 1980s with Risk Assessments for the 1990s", American Journal of Political Science, 41(4): 1079-1103.

Haavelmo, T. (1954) A Study in the Theory of Economic Evolution, Amsterdam: North-Holland. Hegre, Håvard, Tanja Ellingsen, Scott Gates and Nils Petter Gleditsch. (2001) "Toward a Democratic Civil Peace? Democracy, Political Change, and Civil War, 1816-1992." American Political Science Review, 95 (1): 33-48.

Hirshleifer, J. (1995) "Theorizing about Conflict", in Handbook of Defense Economics, edited by K.Hartley and T. Sandler, vol. 1, Amsterdam: Elsevier: 165-192.

Huber, E., D. Rueschemeyer and J. Stephens (1993), "The Impact of Economic Development on Democracy", Journal of Economic Perspectives, 7(3): 71-85.

ICPSR, World Values Surveys and European Values Surveys, 1981-1984, 1990-1993, and 1995-1997 [computer file]. Colchester, Essex: UK Data Archive [distributor], 21 February 2000. SN: 4366.

Indyk, M. (2002) "Back to the Bazaar", Foreign Affairs, January-February,

Knack, S. and P. Keefer (1997) "Does Social Capital Have an Economic Payoff? A CrossCountry Investigation", Quarterly Journal of Economics, 112(4): 1251-88.

Kuran, T. (1991) "The East European Revolution of 1989: Is It Surprising that We Were Surprised?", American Economic Review, 81(2): 121-125.

Lohmann, S. (1994) "The Dynamics of Informational Cascades: The Monday Demonstrations in Leipzig, East Germany, 1989-91", World Politics 47 (October): 42101.

Luttmer, E. (2001) "Group Loyalty and the Taste for Redistribution", Journal of Political Economy, 109(3): 500-528.

MacCulloch, R. (2000a) "Income Inequality and the Taste for Revolt", London School of Economics, STICERD Working Paper Series No. 29. 
MacCulloch, R. (2000b) “The Impact of Income on the Taste for Revolt", London School of Economics, STICERD Working Paper Series No. 30.

MacCulloch, R. (2001) “The Taste for Revolt”, Economics Letters (forthcoming).

Marx, K. (1844) “Contribution to the Critique of Hegel's Philosophy of Right", in DeutschFranzosische Jabrbucher.

Marx, K. (1887) Das Kapital, Moscow: Progress Publishers.

Moulton, B. (1986) "Random Group Effects and the Precision of Regression Estimates", Journal of Econometrics, 32: 385-397.

North, D. and B. Weingast (1989) "Constitutions and commitment: the evolution of institutions governing public choice in seventeenth-century England", The Journal of Economic History, 49(4).

Olson, M. (1965) The Logic of Collective Action, Cambridge: Harvard University Press.

Persson, Torsten and Guido Tabellini (2000), Political Economics: Explaining Economic Policy, Cambridge, MIT Press.

Reynal-Querol, M. (2002) "Ethnicity, Political Systems and Civil Wars", Journal of Conflict Resolution 46(1): 29-54.

Roemer, J. (1998) "Why the Poor do not Expropriate the Rich: An Old Argument in New Garb", Journal of Public Economics, 70: 399-424.

Sambanis, N. (2001) "A Review of Recent Advances and Future Directions in the Quantitative Literature on Civil War", Yale University Working Paper.

Schumpeter, J. (1991) "The Crisis of the Tax State", in Joseph A. Schumpeter: The Economics and Sociology of Capitalism, Ed.: Richard Swedberg, Princeton, NJ: Princeton University Press.

Skaperdas, S. (1991) "Conflict and Attitudes Toward Risk", American Economic Review, 81(2): 116-120.

Skaperdas, S. (1992) "Cooperation, Conflict, and Power in the Absence of Property Rights", American Economic Review, 82(4): 720-739.

Tarrow, S. (1989) Struggle, Politics and Reform: Collective Action and Politics ${ }_{2}$ NY: Cambridge University Press.

Tilly, C. (1978) From Mobilization to Revolution, Reading, MA: Random House.

Tullock, G. (1974) The Social Dilemma: the Economics of $W$ ar and Revolution, Center for the Study of Public Choice, Fairfax, VA. 